\title{
DIE SUID-AFRIKAANSE BLANKE JEUG IN DIE TWEEDE VRYHEIDSOORLOG
}

\author{
Mnr J.A. Visser*
}

This article is a detailed description of the lives of white Youths during the Second War of Independence in South Africa. The plight of children confined in concentration camps all over the country, the high death rate due to malnutrition and the outbreak of disease in the camps are analysed and the attention is focussed on the allarming fact that whereas 6189 burghers died during this war, a total of 27,927 men, women and children died in concentration camps during the same period. It can thus safely be said that it was much safer at the front than in a concentration camp.

Examples of extraordinary valour by young children were numerous during this war and some of these are related in the article.

\section{Kinders in konsentrasiekampe}

Die Tweede Vryheidsoorlog het baie langer geduur as wat Engeland verwag het. 'n Oorlog wat slegs drie maande sou duur het twee jaar en sewe maande geneem om tot ' $n$ einde te kom. Toe die oorlog teen die einde van 1899 nog nie beëindig is nie, was dit duidelik dat verskeie van die Britse bevelvoerders daarop uit was om die bepalings van die Konvensie van Den Haag ten opsigte van die nie-vegtendes te verontagsaam en het hulle oorgegaan om ' $n$ beleid van brandstigting en verwoesting te volg. So was daar aan die einde van 1899 en die begin van 1900 reeds 18 huise in die distrik van Jacobsdal, in die Vrystaat, gedeeltelik verbrand of in puin gelê. ${ }^{1}$
Die persone wat die meeste onder hierdie verwoestingswerk van die Engelse gely het, was nie die vegtende burgers nie, maar die vrouens, kinders en grysaards. Deur die huise af te brand is die vrouens, kinders en grysaards sonder voedsel of deksel op die plase agtergelaat en die Britse soldate het hulle nie daaroor bekommer of hulle van ellende en honger sou omkom nie. $^{2}$

Vrouens en kinders wat by die afgebrande plaashuise agtergelaat is, moes hulle toevlug tot hulle bure neem wat in sommige gevalle in net so 'n haglike toestand verkeer het. Bejaardes wat vir krygsdiens ongeskik en in sommige gevalle siek was, is as krygsgevangenes wegge-

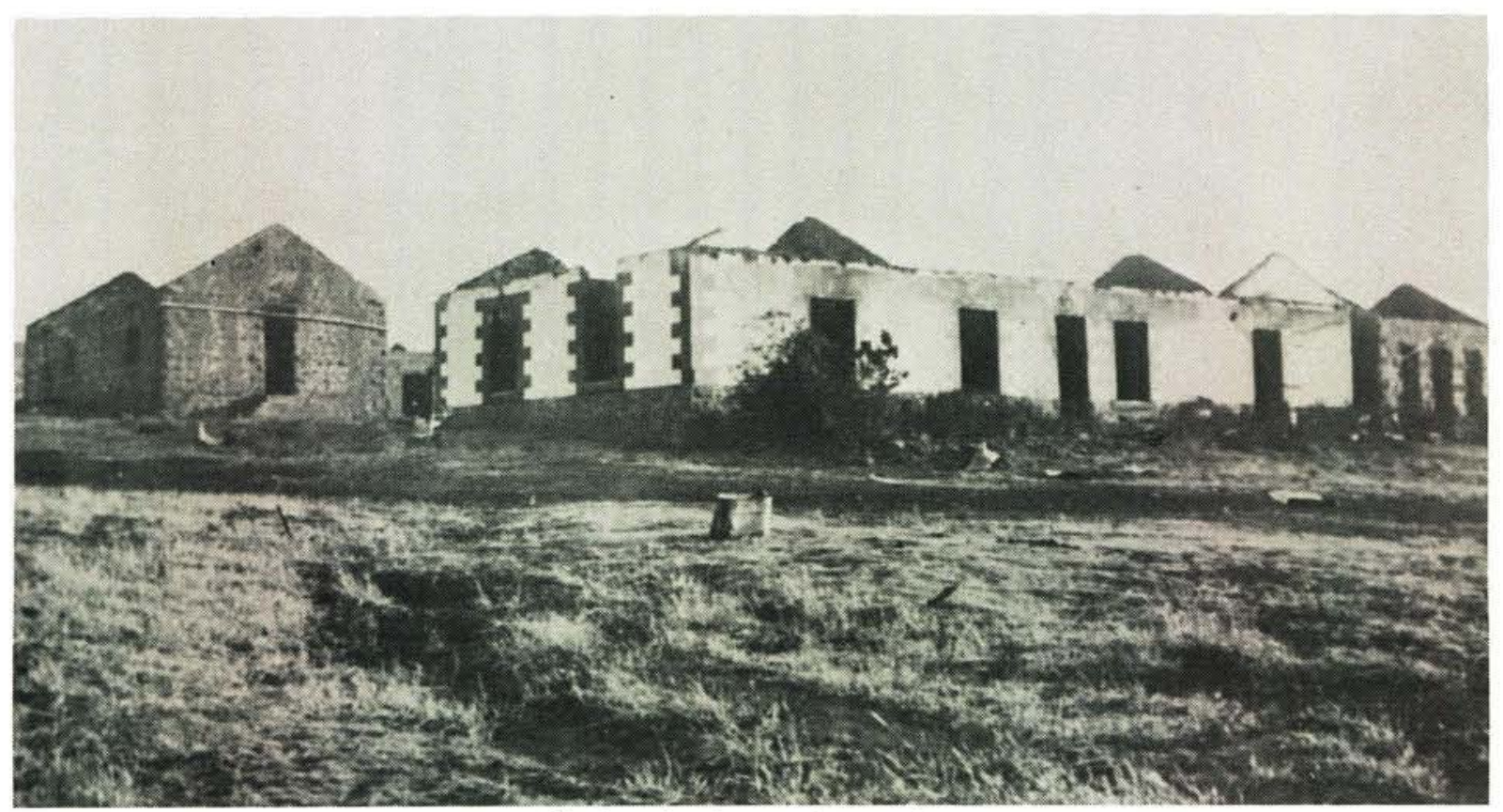

Afgebrande plaaswoning en skuur (Foto: Nasionale Kultuurhistoriese en Opelugmuseum) 
voer. Daar het selfs gevalle voorgekom waar nie net die plaashuis afgebrand is nie maar waar al die voedsel gekonfiskeer of net vernietig is sodat daar niks oorgebly het waarvan die agtergelate vrouens en kinders kon lewe nie. Die Britse opperbevel het gereken dat om die voedsel van die vrouens en kinders weg te neem, die boere gedwing sou word om oor te gee. Meer en meer gesinne is van hul bestaansmoontlikhede beroof en het na hul huise in die dorpe of huise van vriende in die dorpe gegaan. Hierdie vrouens en kinders het egter nie soos die Britse opperbevel skynbaar gehoop het na die boerekommando's in die veld gegaan om hulle mans te smeek om die stryd te staak nie. Die enigste uitwerking wat dit op hulle gehad het was ' $n$ gevoel van verbittering teenoor die Engelse en hul is met vuriger vaderlandsliefde besiel. ${ }^{3}$

Toe die vernietiging en verwoesting van eiendom nie baat nie, het Lord Roberts op 19 Junie 1900 'n verklaring uitgereik waardeur vrouens en kinders van vegtende burgers vir onderhoud na die boerekommando's gestuur sou word. Om sy saak te regverdig het hy aangevoer dat gebrek aan lewensmiddele hom daartoe dwing. Sy optrede om weerlose vrouens en kinders in die gevaarsfeer te bring was net om te probeer om met al die middels tot sy beskikking die oorlog so spoedig moontlik tot ' $n$ einde te bring. Voor die einde van Augustus 1900 was daar reeds meer as ' $n$ duisend vrouens met hul kinders op die nekke van die vegtende boere afgelaai. Hierdie vrouens en kinders is in oop bees- en steenkooltrokke vervoer en die foltering wat hulle moes deurmaak, was onbeskryflik. In die tussentyd het die Transvaalse Regering en President Steyn te Nelspruit met mekaar beraadslaag oor wat om met die vrouens en hul kinders, wat nou na die gevegslinies verplaas gaan word, gedoen moes word. Na deeglike oorweging is besluit om twee stoombote in Delagoabaai te huur om die vrouens en kinders na Europa te stuur. Toe Lord Roberts van hierdie plan verneem, het hy van sy plan afgesien omdat hy besef het dat dit die Britse oorlogspoging sou bemoeilik en omdat die honderde boerevrouens en kinders wat na Europa sou gaan nie net die simpatie van die Europese volkere sou verkry nie maar dat weifelende regerings dit moeilik sou vind om hul neutraliteit te bewaar. $^{4}$

Die Britse opperbevelhebber het nuwe planne beraam om deur middel van druk op vroue en kinders die moraal van die vegtende burgers te probeer breek en om sodoende die oorlog gou tot ' $n$ einde te bring. Die Britse militêre owerheid in Suid-Afrika het besluit om alle vrouens en kinders van vegtende boere in konsentrasie-

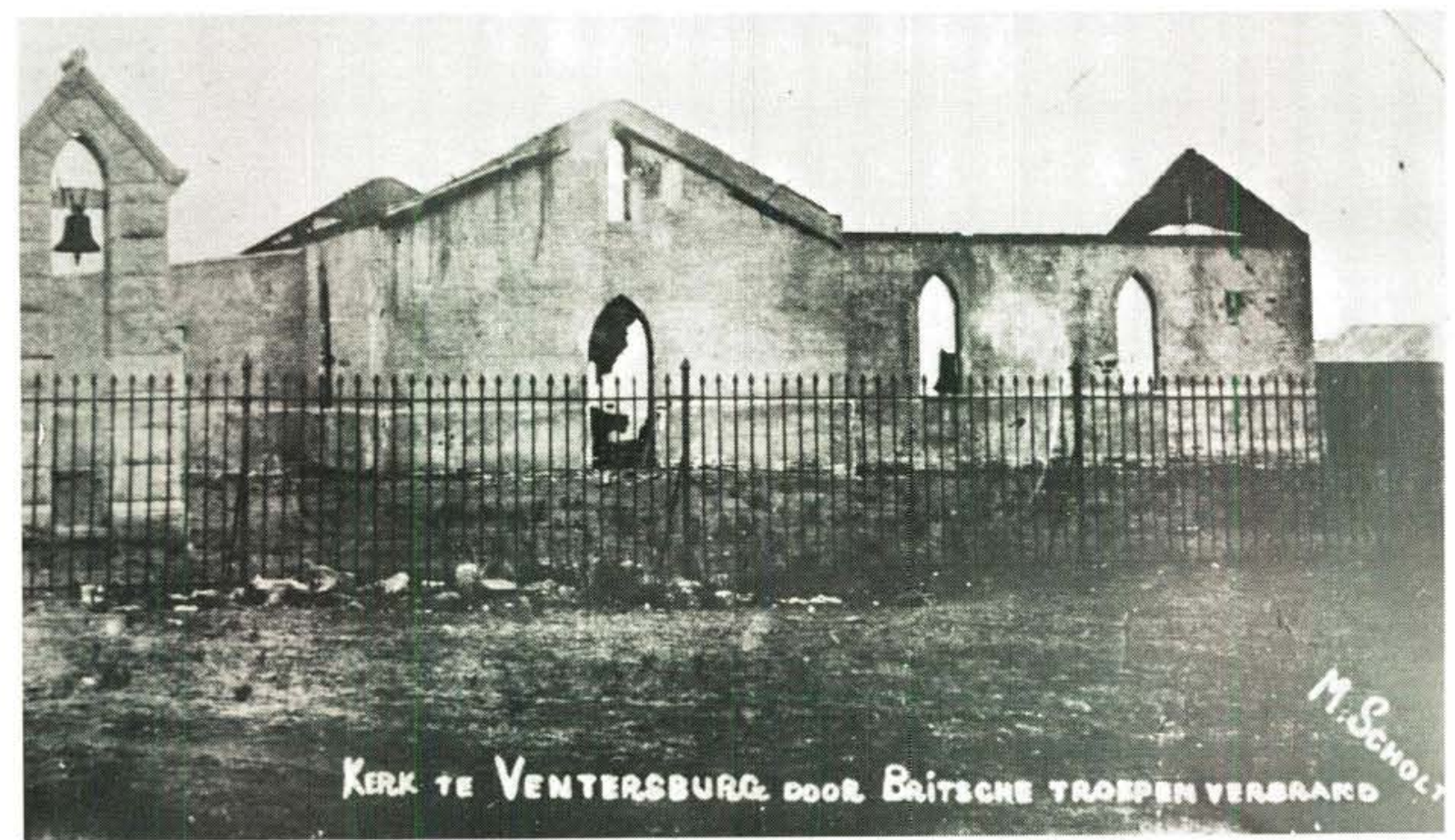

Afgebrande kerk te Ventersburg in die Oranje-Vrystaat (Foto: Nasionale Kultuurhistoriese en Opelugmuseum) 
kampe saam te trek. As vernaamste rede vir die stigting van konsentrasiekampe is aangegee die vernietiging van alle voorrade en vee en die verbranding van huise ten einde die boere tot oorgawe te dwing. Die vegtende boere sou dan nie meer voorrade op die plase, waar die vrouens die boerdery voortgesit het, kon kry nie. Nog 'n rede wat aangevoer is, was dat die vrouens op die plase as spioene vir die boerekommando's opgetree het en om die rede verwyder moes word. ${ }^{5}$

Teen September 1900 is oorgegaan tot die stigting van konsentrasiekampe wat op die Weylermetode geskoei was. Dit was die metode wat die Spaanse generaal, Weyler, gevolg het om die Kubaanse opstand teen Spanje in 1895 te onderdruk. Weyler se metode het daaruit bestaan om loopgrawe, doringdraadheinings en blokhuise oor die smal dele van die eiland te bou. Op hierdie wyse het hy volkome beheer oor die dorpe gekry en het hy begin om die land stelselmatig te verwoes deur die opstandelinge uit te honger en tot oorgawe te dwing ${ }^{6}$

Nadat die boerewonings op die plase afgebrand is, is die nie-vegtendes wat uit vroue, kinders en grysaards bestaan het na die dorpe geneem en in konsentrasiekampe geplaas. Die toestande in die konsentrasiekampe was so swak dat duisende mense, veral kinders, hier gesterf het. In die konsentrasiekampe was daar tonele wat die beskaafde wêreld met afsku vervul het en die stelsel is allerweë verdoem. ${ }^{?}$

Die kampe wat tot Augustus 1900 opgerig is, is dan ook met reg "Refugee"-kampe genoem want dit het uitsluitlik gedien as beskerming vir "hendsoppers" en verraaierfamilies. Boge- noemde kampe was nie bedoel om huisvesting te bied aan families van burgers wat hulle land getrou bly dien het en wie se huise afgebrand is nie. Sedert September 1900 is families van vegtende burgers krygsgevangene geneem en na verskillende "Refugee"-kampe geneem sodat die kampe hul karakter verloor het aangesien daar nou nie net "refugees" hier gehuisves is nie, maar die inwoners het ook uit vroue en kinders wat daarheen gedwing is, bestaan. Boerehuise op die plase is met geweld binnegedring, na willekeur gestroop, terwyl die diere op die werf voor die voet afgemaak is. Aan die vroue is ' $n$ kort tydjie gegee om 'n paar kledingstukke en beddegoed uit die huis te neem voor dit in vlamme opgegaan het. Die Engelse troepe het hul weinig aan siekes en invalides gesteur. ${ }^{8}$

Van die vrouens en kinders is toegelaat om in hul eie tentwaens na die kampe vervoer te word maar die meeste is op oop waens en trollies vervoer en hulle moes die natuurelemente van koue gedurende die winter en hitte, reën en hael gedurende die somer, trotseer. Die kinders het die swaarste gekry. In gevalle waar daar nie vervoer beskikbaar was nie, moes die vrouens en kinders te voet loop en is hul te perd aangejaag deur soldate of selfs naturelle en kleurlinge. Verder was daar die families wat per trein na hul bestemmings gestuur is of wat van een kamp na ' $n$ ander verskuif is. Laasgenoemde gevalle is hoofsaaklik in oop trokke vervoer. Die ontberings wat die vrouens en kinders op die oop trokke moes verduur, is onbeskryflik want dit was nie net die koue of hitte, dors en honç er nie, maar daar was ook geen privaat geriewe nie ${ }^{9}$

Omtrent die vervoer per oop trokke skrywe Emily

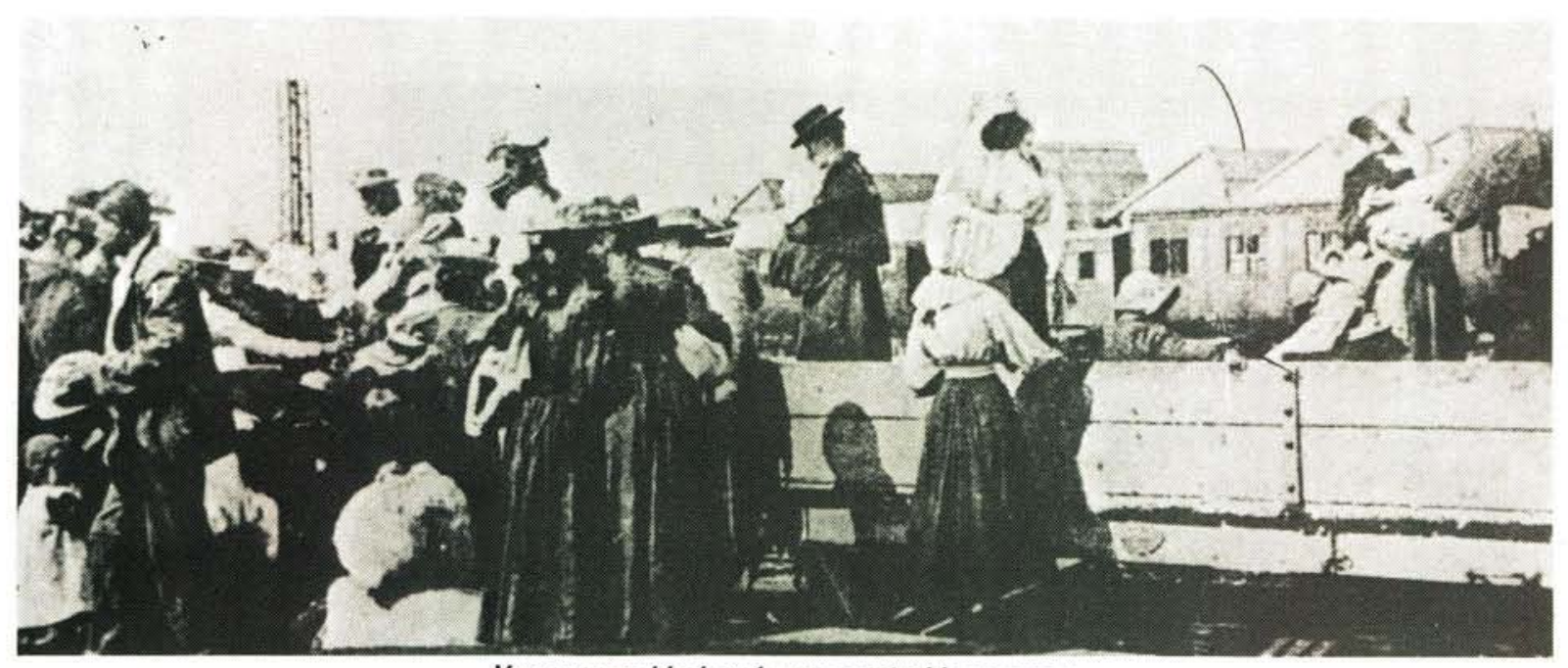

Vrouens en kinders is op oop trokke vervoer 
Hobhouse na die oorlog as volg: "Fearing the result upon sick and famished people of the rough military organization, I had begged to be allowed to supervise this removal. I was refused and my worst fears were realized. The people, most of whom were unfit to travel, were sent to a marsh in Natal like Merebank, or carried infection to a healthy camp like Howick. Preparation for them was inadequate and they were exposed to poignant sufferings on the journey. Many cultivated women whom I have met, have told me that they feel unable ever to let their thoughts dwell for an instant upon the horrors of those enforced and cruel journeys, locked into crowded trucks and not allowed to leave them for any purpose whatsoever."10

Konsentrasiekampe is op die volgende plekke opgerig:

\section{Transvaal}

Balmoral

Barberton

Belfast

Heidelberg

Irene

Johannesburg

Klerksdorp

Krugersdorp

Meintjeskop

Middelburg

Nylstroom

Pietersburg

Potchefstroom

Standerton

Vereeniging

Volksrust

\section{Natal}

Colenso

Eshowe

Howick

Jacobs

Ladysmith

Merebank

Pietermaritzburg

Een van die hoofgebreke van die konsentrasiekampe was 'n gebrek aan huisvesting. Daagliks het daar ' $n$ groot hoeveelheid vrouens en kinders opgedaag sonder dat daar die nodige huisvesting vir hulle beskikbaar was. Hulle moes soms vir twee dae en nagte onder die blote hemel deurbring voordat huisvesting verskaf is. Die huisvesting in die konsentrasiekampe was ondoeltreffend, onvoldoende en het veel te wense oorgelaat. Die konsentrasiekampe was oorbevolk en tot 20 persone is saamgehok in tente wat net geskik was vir 4 of 5 persone. Die oorvol tente was vrugbare teelaarde vir siektekieme veral van aansteeklike siektes met die gevolg dat dit nie net die siektes vererger het nie maar dit veroorsaak het. ${ }^{12}$

Op die hoëveld het die koue wintermaande sy tol geëis. Nie alleen is die tente deur die wind in flarde geskeur nie maar die koue het baie lewens geëis waar die kinders op die grond sonder matrasse en baie min komberse moes slaap. 'n Persentasie van die kampbewoners waaronder selfs verwagtende moeders was, moes op die grond slaap. Mej Hobhouse het so ver gegaan om aan te bied om matrasse te maak in-

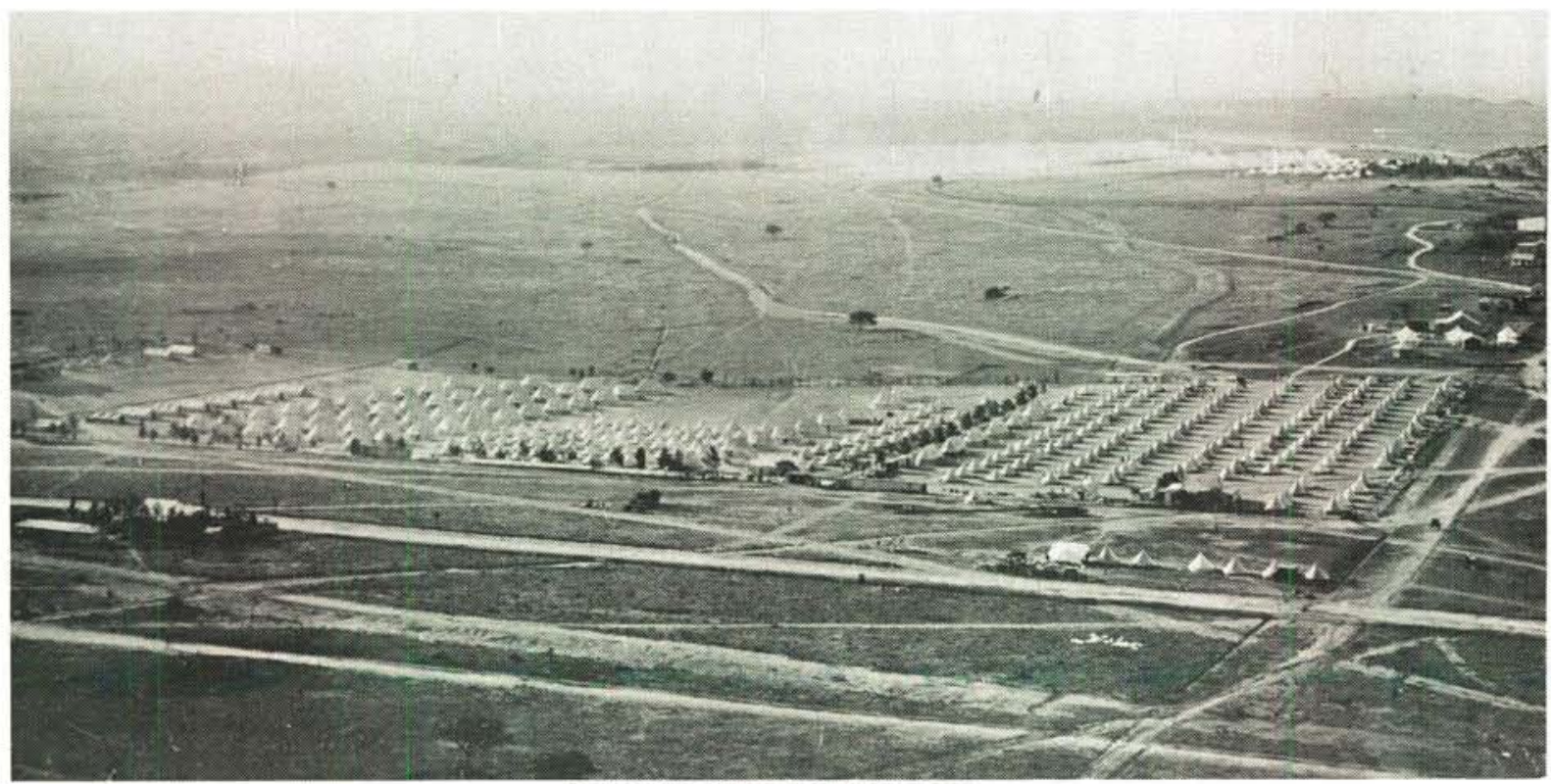

Konsentrasiekamp te Barberton

(Foto: Nasionale Kultuurhistoriese en Opelugmuseum) 
dien die strooi deur die militêre owerheid aan haar verskaf word. Selfs dit kon nie eers in 'n geringe hoeveelheid verskaf word nie. Toestande is verder vererger deurdat die terrein waar sommige van die kampe opgerig is, hopeloos ondoeltreffend was. By Standerton was die kamp aan die oewers van die Vaalrivier opgerig. Gedurende die winter was dit bitterkoud terwyl dit in somermaande modderig en nat was. Die Dameskomitee wat die konsentrasiekampe besoek het, het dan ook aanbeveel dat verskeie kampe in Transvaal en die Vrystaat verskuif moes word. Die terrein van die Merebankkamp in Natal is ten sterkste afgekeur. Die kamp was aan die voet van 'n lae koppie geleë en water het gedurig uit die koppie tot in die kamp deurgesyfer. Aan die Durbankant van die kamp was daar 'n moeras wat na die kamp gedreineer het. Die terrein was so nat dat grafte nouliks dieper as vier en 'n half voet gegrawe kon word, voordat water daarin uitgeborrel het. ${ }^{13}$

Die vernaamste rede vir die hoë sterfte- en siektesyfer was die onvoorbereidheid en haastige optrede van die militêre owerhede met die oprigting van kampe. Daar was vooraf geen beplanning gemaak nie met die gevolg dat daar 'n groot gebrek aan lewensnoodsaaklike voorrade, huisvesting, mediese dienste, ensovoorts ontstaan het. Daar was geen behoorlike voorsiening vir voeding, hospitaalakkommodasie, verpleegsters, dokters en die versorging van siekes gemaak nie, al die konsentrasiekampe is halsoorkop deur die land opgerig. ${ }^{14}$

Lord Kitchener was die persoon wat die kampe van militêre tot siviele beheer oorgeskakel het. Die militêre offisiere sou voortaan net vir die uitwendige verdediging van die kamp verantwoordelik wees en aan die superintendente alle moontlike hulp verleen. Met die organisasie van die kampe was daar 'n groot skroef los want tente was onverkrygbaar; voedselvoorsiening swak, onvoldoende en baie vertraag; materiaal vir noodsaaklike geboue was soms vir maande onverkrygbaar; noodsaaklike geboue soos latrines vir mans, vroue en kinders was uiters beperk en primitiewe skerms is vir die doel aangewend; doodskiste is uit planke van seepkissies en melkkassies gemaak; daar was geen baddens, badkamers, washuise, beddens, tafels, ensovoorts nie en die kampe was oorbevolk. ${ }^{15}$

Die weersinswekkende metodes soos die in-

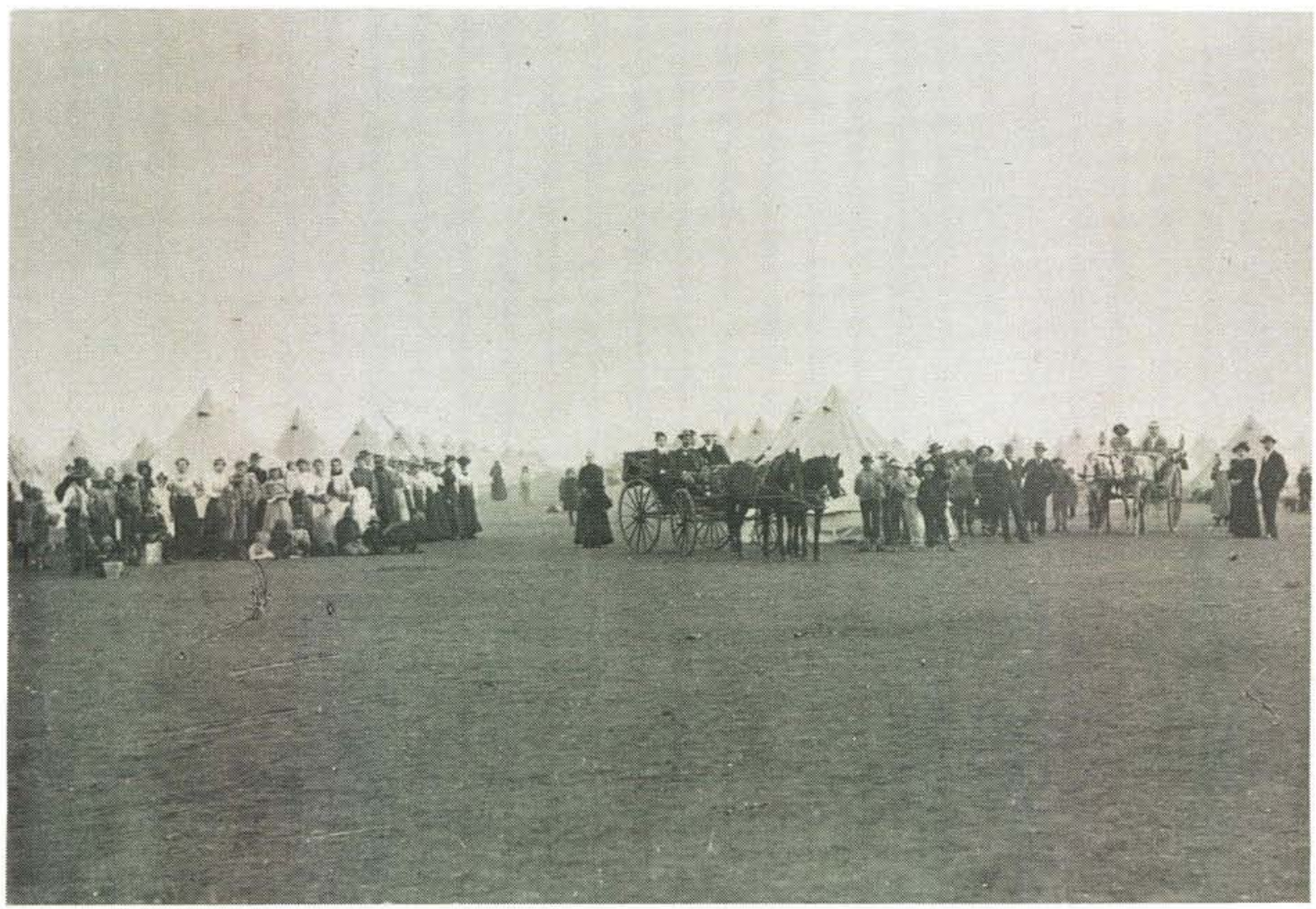

Konsentrasiekamp te Klerksdorp (Foto: Nasionale Kultuurhistoriese en Opelugmuseum) 
kamping van vroue en kinders in kampe het mettertyd verset en vernedering van vroue teweeggebring en ' $n$ sterk anti-Britse gevoel by hulle veroorsaak. Die strafmaatreëls teen vroue in die kampe toegepas soos die uitreiking van halwe rantsoene en intronking, het die boeretrots gekrenk maar dit kon nie die boerekarakter vernietig nie. Dat strafmaatreëls in sommige gevalle noodsaaklik was, is begryplik maar dat dit soms oordryf is, val nie te betwyfel nie. ${ }^{16}$

Een van die aangeleenthede waaroor daar die meeste in die konsentrasiekampe gekla is, was die voorsiening van voedsel aan die gevange burgerfamilies. By die toekenning van rantsoene is daar vir die Transvaal sowel as die Vrystaat tussen twee groepe persone onderskei naamlik "bona fide refugees, who have come in for protection from Boers" (Transvaal) en "Refugees" (Vrystaat) aan die een kant en "all other classes of refugees" (Transvaal) of "undesirables" (Vrystaat) aan die ander kant. Die persone wat op die hoër rantsoenskaal geplaas is, was bekend as die A-skaal, die sogenaamde "bone fide refugees, who have come in for protection from Boers" (Transvaal), en "Refugees" (Vrystaat), het bestaan uit huisgesinne van wie die manlike hoofde "hendsoppers" of verraaiers was. Die laer rantsoenskaal, bekend as die B-skaal het bestaan uit die huisgesinne wie se mans getrou gebly het aan land en volk en voortgeveg het. Deur die verminderde rantsoene (B-skaal) is die huisgesinne gestraf vir die pligsgetrouheid en wetsgehoorsaamheid van hul mans. ${ }^{17}$

Die Transvaalse rantsoenskaal het uit die volgende bestaan:

\section{"Refugees" (A-skaal per week)}

$7 \mathrm{lb}$ meelblom of boermeel

$1 \mathrm{lb}$ vleis twee keer per week

4 onse sout

6 onse koffie

12 onse suiker

"Undesirables" (B-skaal per week)

7 lb meel

Geen vleis

4 onse sout

4 onse koffie

8 onse suiker

\section{Kinders onder twaalf jaar per week}

$3 \frac{1}{2} \mathrm{lb}$ meelblom of boermeel

$\frac{1}{2} \mathrm{lb}$ vleis twee keer per week

2 onse sout

3 onse koffie

12 onse suiker

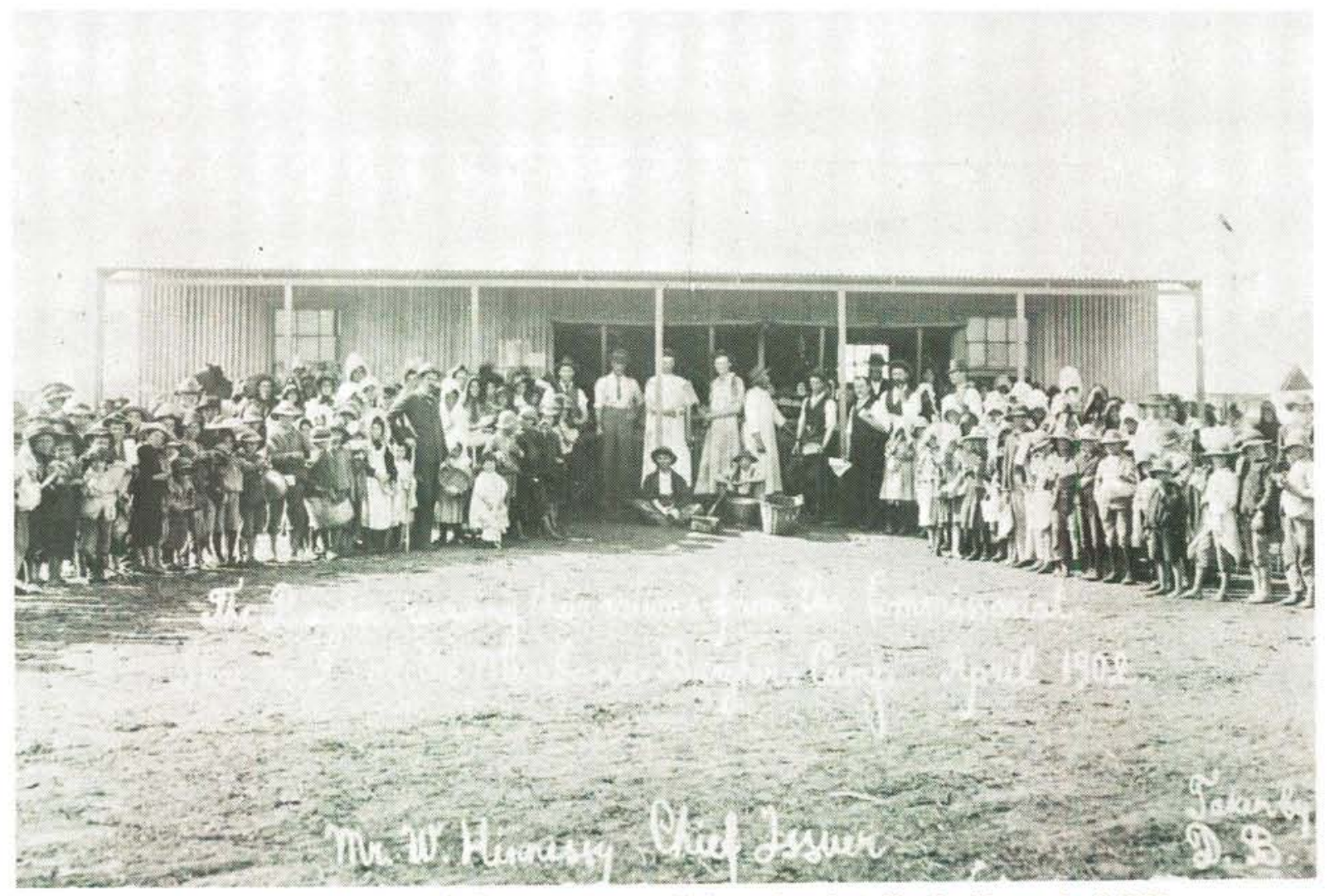

Kampbewoners ontvang hulle rantsoene van die kommissariaat. Merebankkamp April 1902 (Foto: Nasionale Kultuurhistoriese en Opelugmuseum) 


\section{B-skaal per week}

$3 \frac{1}{2} \mathrm{lb}$ meelblom of boermeel

Geen vleis

2 onse sout

2 onse koffie

8 onse suiker ${ }^{18}$

Die Vrystaatse rantsoenskaal het uit die volgende bestaan:

\section{"Refugees" (A-skaal per dag)}

$\frac{1}{2} \mathrm{lb}$ vars vleis

$\frac{1}{2} \mathrm{lb}$ meel, rys, gestampte mielies of ertappels

$1 \frac{1}{2}$ ons koffie

3 onse suiker

1 ons sout

$\frac{1}{12}$ blik gekondenseerde melk

\section{"Undesirables" (B-skaal per dag)}

$\frac{1}{2} \mathrm{lb}$ vars vleis

$\frac{1}{2} \mathrm{lb}$ meel, rys of gestampte mielies

$\frac{1}{2}$ ons koffie

1 ons suiker

1 ons sout

$\frac{1}{18}$ blik gekondenseerde melk ${ }^{19}$

Uit die bogenoemde rantsoenskale is dit duidelik dat daar nie noodsaaklike voedsels soos groente, vrugte of vars melk verskaf is nie. Die Engelse militêre owerheid het gereken dat die dinge wat nie deur hulle verskaf word nie, deur die kampbewoners self by die kampwinkels aangekoop kon word. Wat betref die "bona fide refugees, who have come in for protection from Boers", kon bogenoemde standpunt nog aanvaar word omdat dit mense was wat deur die militêre instansies vergoed is vir al hul goedere wat opgekommandeer is en verder het hulle allerlei werkies teen vergoeding in die kampe verrig - hulle het dus oor geld beskik om sekere lewensbehoeftes aan te koop. Die mense wat baie swaar gekry het was die "undesirables" of "all other classes" wat by hul gevangeneming van byna al hul aardse besittings ontroof is en ook geen verdienste in die kampe ontvang het nie. Onder hierdie tweede groep het die oorgrote meerderheid van kampbewoners geressorteer. As voedsel om een of ander rede nie betyds afgelewer is nie, het hierdie mense hongersnood in die oë gestaar. ${ }^{20}$

Daar het baie klagtes oor die voedselrantsoene bestaan maar in weerwil van al die rapporte van geneeshere, bevindings van besoeksters, toesprake van vooraanstaande persone en talle ander getuienisse, het die Britse owerheid volstaan dat die rantsoene voldoende was en ook beweer dat die voedsel presies dieselfde was as die wat aan die Britse troepe verskaf is. Dit was wel waar in soverre dit persone betref wat die A- rantsoenskaal ontvang het $\mathrm{nl}$. die "hendsopperfamilies", maar dit was ver van die waarheid wat die persone betref wat die B-rantsoenskaal ontvang het nl. die "undesirables" of "all other classes" wat op die sogenaamde "halwe"rantsoenskaal geplaas is. ${ }^{21}$

Dit was duidelik dat die oorgrote meerderheid van die vrouens en veral kinders van die verskillende kampe, deur die plasing op die "halwe"rantsoenskaal, doelbewus deur die militêre owerhede verhonger is. Om dit te bewys skrywe die joernalis, W.T. Stead, in verband met die aangeleentheid: "But let us assume that the full ration represented the irreducible minimum upon which the Government would feed its prisoners of war. It is then deliberately determined, apparently upon the authority of Lord Kitchener and with the sanction of Mr Brodrick, to subject the women and children whose husbands and fathers were still obeying the orders of their Government, in defending their country against the invader, to a policy of systematic starvation. To a woman whose husband was on commando, to the helpless child of a man who had not yet laid down his arms, the decree went forth that they should be deprived of one half of the rations necessary for their proper sustenance. Starvation was thus deliberately employed as an engine of torture in order, by the suffering inflicted upon their women and children, to induce their men-folk to desert the ranks, and for pity's sake to sacrifice the cause of their country. We could neither kill, wound, nor capture the burghers who were still in the field. But we could catch their helpless children. Having caught them we could pen them in our substitute for the Spanish Inquisition, the Prison Camps. Instead of stretching them upon the rack, using the thumb-screw, or applying the red-hot iron to the soles of their feet, we achieve the same result by inflicting the refined and horrible torture of slow starvation. Under this peine forte et dure the children sickened, pined away to living skeletons, and then happily were released by death from their sufferings. Every one of these children who so died as the result of the cutting down of rations by half, in order to bring pressure to bear upon their relatives in the field, was as deliberately murdered as were any of the Irish babies whom General Carey spitted in the campaign against the renegade traitors of Munster. The prison camp itself may not have originally been intended as a place of torture or as a means of putting pressure upon the burghers; but the half-ration system stands revealed, naked and unshamed, as a deliberate act of state policy employed for the 
purpose of compelling the surrender of foes whom we were unable to overcome in the field. ${ }^{22}$

Daar het so baie klagtes ingekom oor die onvoldoende voedsel van die halwe-rantsoene dat daar op 27 Februarie 1901 instruksies uitgereik is waarvolgens al die kampinwoners op die " $A$ "skaal geplaas is. Dit het ' $n$ tyd geneem voor dit in al die kampe ingevoer is en voortaan is die "B"-skaal slegs as strafmaatreëls vir weerspannige vroue gebruik. ${ }^{23}$

Daar het ook baie klagtes ontstaan oor die gehalte van vleis wat as rantsoene uitgereik is. Die vleis was ontsettend maer en dit het by verskeie geleenthede gebeur dat die vleis afgekeur is omdat dit ongeskik was vir menslike gebruik. Daar was nie weivelde vir die diere nie met die gevolg dat baie diere soos skape en beeste so maer was dat dit nie geslag kon word nie. By die meeste slagpale en slaghuise was die toestande baie onhigiënies sodat daar onsuiwerhede in die vleis voorgekom het. Toe al die maer diere opgeslag is, is die toevlug tot blikkiesvleis (corned beef) geneem. Dit het spoedig geblyk dat die kampinwoners teensinnig was om die blikkiesvleis te eet en dat dit ook veral vir kinders, ongesond was om te eet. Daar is toe getrag om bevrore vleis te voorsien. Die bevrore vleis kon egter nie altyd voorsien word nie en daar was ook nie die nodige bergingsfasiliteite in die kampe nie met die gevolg dat daar soms nog op buitgemaakte veestapels en blikkiesvleis teruggeval moes word. Die gereelde verskaffing van goeie vleis het die gesondheidstoestande in die kampe bevorder wat duidelik in die afname van die sterftesyfer waarneembaar was. ${ }^{24}$

Dit was nie net die vleis wat van swak gehalte was nie, maar ook die meel, suiker en koffie. In baie gevalle was die bogenoemde artikels onbruikbaar. Dit was opvallend dat kinders sowel as volwassenes dieselfde voedsel ontvang het, daar was geen spesiale voedsel vir kinders voorsien nie. Die rantsoenskale het geen voorsiening vir vars melk gemaak nie maar alleen vir blikkiesmelk wat in sulke klein hoeveelhede voorsien is, byvoorbeeld $\frac{1}{12}$ blikkie per dag (Vrystaatse kampe), dat dit heeltemal onvoldoende was. $^{25}$

Dit is vanselfsprekend dat kindertjies nie kon lewe van dieselfde voedselstowwe as volwassenes of soldate nie. Die swak voedsel het diarree (buikloop) veroorsaak en as gevolg van die tekort aan sekere voedingstowwe in hul dieet het hulle uitgeteer en hul weerstandvermoë teen siektes het afgeneem. Moeders was verplig om hul babas vroeg te speen omdat hulle weens veelvuldige ontberings nie kon volhou om hulle te voed nie en dit was noodsaaklik dat ' $n$ ruim voorsiening van melk aan die babas gemaak moes word wat nie geskied het nie. Die Britse owerhede het hulle egter nie verknies oor die haglike toestande waarin kindertjies verkeer het nie. Dit sou mense soos Emily Hobhouse, en die gade van die Militêre Goewerneur, Maxwell Kendal Franks en die Dameskomitee se onthullings wees wat die Britse regering onder die besef sou bring dat die konsentrasiekampe, sover dit dié kindertjies betref, niks anders as "moordkampe" was nie. ${ }^{26}$

Die Dameskomitee het die abnormale hoë sterftesyfer van kinders onder 5 jaar toegeskrywe aan onvoldoende voedselvoorsiening en gesê: "Whereever a community of little children is found who have to be fed without fresh milk, fresh vegetables, or eggs, a high death-rate will follow as certainly as night will follow day." Nadat hulle die kampe besoek het, het hulle 'n revolusionêre verandering in die bestaande rantsoenskale aanbeveel. Die nuwe rantsoenskale was van so ' $n$ aard dat die hoeveelheid sowel as die voedingswaarde wat die skaal inhou ' $n$ gesonde gestel kon opbou en 'n weerstandvermoë teen siektes kon ontwikkel. Van besondere belang was die rantsoenskaal wat vir kleuters onder 3 jaar aanbeveel is naamlik 2 bottels melk per dag, $\frac{1}{2} \mathrm{lb}$ hawermout en $\frac{1}{2} \mathrm{lb}$ stroop per week asook $\frac{1}{2} \mathrm{lb}$ seep per week. ${ }^{27}$

Die Britse regering het besef dat iets gedoen moes word om die sterftesyfer onder kinders in die kampe omlaag te dwing anders sou die goeie naam van Groot-Brittanje daarmee heen wees. Die Britse regering het 'n komitee, bestaande uit mediese deskundiges in Transvaal, benoem om die hele aangeleentheid van rantsoenskale te ondersoek en om 'n nuwe op te stel. Die komitee het nie slegs die aanbevelings van die Dameskomitee in ag geneem nie, maar die kampdokters ook in die saak geken. Op 13 Januarie 1902 het die nuwe weeklikse rantsoenskale in werking getree en het soos volg daar uitgesien:

\section{Kinders onder 2 jaar - Per week}

14 kwarte melk

$2 \frac{1}{2} \mathrm{lb}$ meelblom of boermeel

6 onse suiker

6 onse stroop

6 onse botter

2 onse sout

8 onse seep 
Soep en groente soos deur die matrone toegeken.

\section{Kinders oor $\mathbf{2}$ jaar maar onder 5 jaar - Per week}

14 Kwarte melk

6 onse stroop

$3 \frac{1}{2} \mathrm{lb}$ meelblom, boer- of hawermeel

6 onse suiker

2 onse botter

2 onse sout

8 onse seep

$2 \mathrm{lb}$ vleis en soep

\section{Volwassenes - Per week}

$7 \mathrm{lb}$ Meelblom of boermeel

12 onse suiker

7 onse koffie

$4 \mathrm{lb}$ vleis

4 onse sout

1 Blik melk

8 onse seep

$1 \mathrm{lb}$ gestampte mielies, rys of bone

24 onse groente ${ }^{28}$

Die voedselrantsoene het eers gedurende die laaste paar maande van die bestaan van die konsentrasiekampe in werking getree en was nie gedoen uit medelye met die boere nie, maar ter beskerming van die goeie naam van Groot-Brittanje. Wanneer daar gepraat word van konsentrasiekampe word outomaties gedink aan hongerkampe, die duisende kindertjies wat gesterf het, swak voedsel soos Bully Beef of uiters maer vleis, swart koffie, slegte meel, swak suiker, geen konfyt, botter of stroop, 'n plek waar vrouens en kinders van vegtende burgers nie eens ' $n$ volle rantsoen maar ' $n$ halwe rantsoen ontvang het ten einde hulle medelydende mans oor te haal om te "hendsop" of verraaiers van hul land te word. ${ }^{29}$

Nog 'n rede vir die hoë sterftesyfer onder kinders was die swak sanitasie. Dit was nie net swak nie maar ook ondoeltreffend, onvoldoende en onhigiënies. By sommige kampe was dit feitlik onmoontlik om privaatplekke te besoek want die stank was so verskriklik dat dit nie moontlik was om daar naby te kom nie. Daar was hopeloos te min latrines vir die aantal inwoners. Daar was ook nie voorsiening vir kinderlatrines gemaak nie met die gevolg dat hulle nie die latrines kon gebruik nie. Namate meer vrouens en kinders na die konsentrasiekampe gebring is, het die latrine-akkomodasie swakker geword omdat die uitbreiding van latrines nie tred gehou het met die snelle toename van die kampbevolking nie. Omdat daar onvoldoende latrines was, het die kampbewoners gebruik gemaak van slote, die walle van riviere en spruite. ${ }^{30}$
Die volgende het verder bygedra tot die toename van siektes en sterftes veral onder kinders $\mathrm{nl}$ vuilis wat uit die tente gevee is, het in hopies bly lê en is nie dadelik verwyder nie; watervoorsiening was swak sodat mense nog hulself nog hul klere kon was; wasplekke in die kampe was onvoldoende; drinkwater was besmet; die oprigting van krematoriums naby kampe om dooie diere te verbrand het nie net 'n onaangename reuk veroorsaak nie maar was ongesond. In soverre dit die higiëniese aangeleenthede betref was die konsentrasiekampe feitlik vir byna die volle tydperk van die bestaan daarvan, swak en ondoeltreffend ingerig en niks anders as broeiplekke van siektekieme wat die oorsaak was van die dood van duisende kindertjies. ${ }^{31}$

Die Britse militêre owerhede het hulle aanvanklik min bekommer oor die gesondheid van die vrouens, grysaards, kinders en suigelinge. Daar was geen mediese geriewe in die kampe aangebring nie en die vroegste behandeling het uit "medical comforts" bestaan wat uit voedsame produkte soos bv melk bestaan het, en ander gebruiksmiddele soos seep en kerse ingesluit het. Dit was dus eintlik middele wat aan al die kampbewoners verskaf moes gewees het. Dit het dus beteken dat die kampbewoners eers pasiënte moes word voordat hulle van die essensiële voedselstowwe en middele voorsien is. In die konsentrasiekampe, in albei republieke, was daar te min mediese personeel, onvoldoende hospitaalakkomodasie, ondoeltreffende en primitiewe apparaat. Die onhigiëniese toestande wat daar in die kampe geheers het, was bevorderlik vir die verspreiding van siektes en die uitbreek van epidemies. ${ }^{32}$

Die werk van medici en verpleegsters is bemoeilik deur die afkerigheid of vrees wat die boervrou en kind vir hospitale en geneeshere gehad het. Die oorsake is maklik te verklaar daar die Engelssprekende en Engelsgesinde geneeshere en verpleegsters nie die vertroue van die boervrouens en kinders geniet het nie. Sommige van hulle het die vrouens en kinders, wat nie Engels kon praat of verstaan nie, baie onsimpatiek en vyandig behandel. ${ }^{33}$

'n Beskuldiging wat teen die moeders ingebring is, was dat hulle nie bevoeg was om hul siek kinders self te verpleeg nie en hulle verwaarloos het. Hierdie aanklag kan as onwaar weerlê word want alhoewel die moeders nie medies geskool was nie, het hulle deur praktiese ervaring in ' $n$ selfonderhoudende gemeenskap nog voor die ontstaan van die kampe getoon dat hulle in staat 
was om hul eie gesinne te verpleeg. In die kampe het hulle daarop aangedring om hul siek kinders self te verpleeg omdat hul groot vertroue in hul eie verpleegmetodes gehad het. Dit is ook die vrouens ten laste gelê dat die Hollandse medisynes (huisapteek) as geneesmiddels geen waarde besit het nie en dat hulle aan allerlei rate soos self die gebruik van groen verf as medisyne geglo het. Ook hierdie bewering was onwaar omdat baie van die ou Hollandse medisynes wel waarde as geneesmiddels gehad het. ${ }^{34}$ Ramsey MacDonald het hom oor die hele aangeleentheid as volg uitgelaat: "and all our gossip about green paint as a medicine and the general filth of the people is simply hypocritical nonsense and ignorant slander. We have to face this fact, which no one who knows the country dare dispute, that the camps were a profound mistake, that families on the veldt or in caves fared better and suffered a lower mortality rate than those in the camps; that the appalling mortality of the camps lies at our doors (one of the saddest things I have ever seen in my life was a camp graveyard, with its crowded tiny crosses; it looked like a nursery of crosses); that the camps have created a fierce bitterness amongst the women and the young generation; that when every other memory of the war will have faded away the nightmare shadow of the camps will remain. ${ }^{35}$
Die redes waarom die siektes in die konsentrasiekampe nie doeltreffend bestry kon word nie, was die volgende: die Britse owerheid het te min opgeleide medici en verpleegsters aan die kampe verskaf om al die siektegevalle te behandel; verpleegsters en geneeshere is benoem nie as gevolg van hul bekwaamheid nie maar op grond van hul lojaliteit jeens Engeland met die gevolg dat hulle die pasiënte omsimpatiek behandel het en dit verklaar ook waarom die kampbewoners ' $n$ afkeer in die kamphospitale en personeel gehad het; daar was nie doelmatige hospitaalgeriewe verskaf nie; daar was geen voorsiening gemaak vir die isolasie van persone wat aan aansteeklike siektes gely het nie en die Britse owerheid het niks gedoen om die oorsake van die ontstaan van siektes te verwyder nie. ${ }^{36}$

Uit al die voorgaande toestande was dit net logies dat siektes soos witseerkeel, masels, skarlakenkoors en ingewandskoors hul verskyning sou maak en dat die dodetal, veral onder kinders, sou toeneem. In Mei 1901 was daar in die Vrystaat 355 sterfgevalle uit ' $n$ kampbevolking van 24887 en in Transvaal 338 uit 'n kampbevolking van 38573 . Trollope, die algemene superintendent van die Vrystaatse kampe asook $\mathrm{dr}$ G.P. Parnell het beweer dat die hoofoorsaak van die sterftes in die kampe toe te skrywe was aan 'n gebrek aan persoonlike en algemene sindelikheid by die kampbewoners. Soos reeds voor-

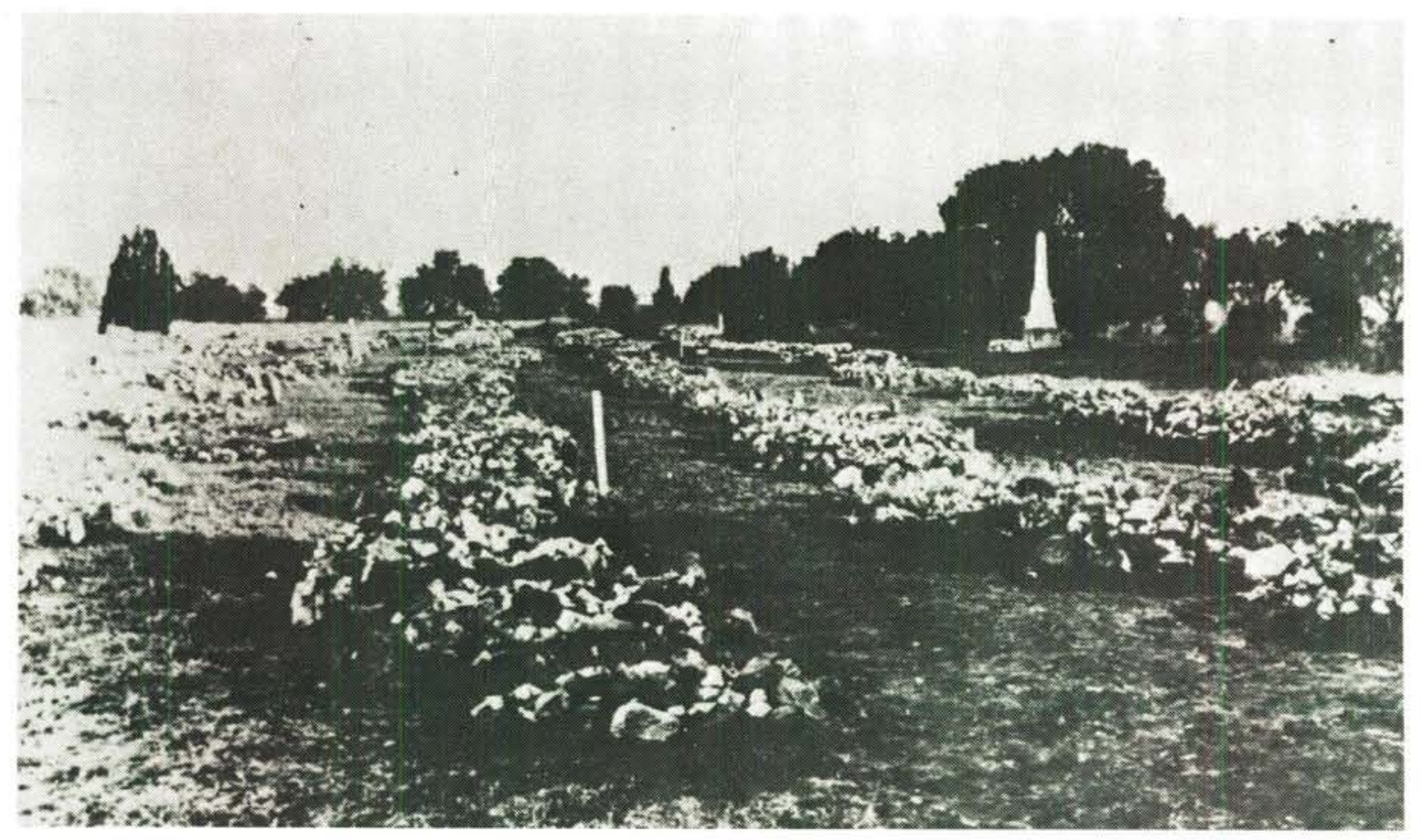

Kindergraffies met klippe versier 
heen vermeld was hierdie bewering onwaar want water en seep en ander fasiliteite wat noodsaaklik is vir die bevordering van reinheid is nie in voldoende hoeveelhede aan die kampbewoners verskaf nie, die administrasie het ook nie die vuilis en nagvuil gereeld verwyder nie en daar was ook nie voldoende doelmatige latrines verskaf nie. Die bewering dat die vroue voor die kamptydperk nie van latrines gebruik gemaak het nie, was ook onwaar want elke dorpserf het sy latrine gehad asook die oorgrote meerderheid van die woonhuise op die plase. ' $n$ Verdere bewering dat nuwe inkomelinge die kampe met siektes besmet het, aangesien hulle die siektes onderlede sou gehad het, is ook onwaar. As bewys dat dit onwaar is dien die volgende: in Bethuliekamp, wat nog in 'n aanvangstadium was, was die sterftesyfer vir Junie slegs 9 uit 'n bevolking van 3440 , en in Heilbron was dit 10 uit ' $n$ bevolkding van 2077 terwyl die gemiddelde sterftesyfer vir die Vrystaatse kampe in daardie maand 149 per duisend per jaar was. In ou gevestigde kampe soos Bloemfontein was die sterftesyfer vir dieselfde maand so hoog as 396 per duisend per jaar. ${ }^{37}$

Nieteenstaande al die verskonings en bewerings asook die kritiek teen die kampstelsel deur opposisie partye in die Britse parlement, het die sterftes in die kampe toegeneem. In Augustus was die posisie in Transvaal as volg: die gemiddelde sterftekoers het gestyg tot 305 (waarvan die sterftesyfer onder kinders 547 per duisend per jaar was). In die Vrystaat het die sterftesyfer tot 332 per duisend per jaar gestyg (met ' $n$ kindersterfte van 482 per duisend per jaar). Die sterftesyfer in sommige kampe was ontsettend hoog soos in Nylstroom waar dit 1564 per duisend per jaar was, wat beteken dat indien die sterfte so sou voortduur die kinderbevolking binne die bestek van agt maande sou uitsterf. In Pietersburgkamp was die kindersterfte 1218 per duisend per jaar en in Kroonstadkamp soveel as 1875 per duisend per jaar. Indien die kindersterftes van laasgenoemde kamp so sou voortduur sou daar na vyf maande geen kinders meer gewees het nie. ${ }^{38}$

In die boek The Brunt of the War deur Emily Hobhouse, pleit sy in 'n brief wat sy op $29 \mathrm{Sep}$ tember 1901 aan mnr Brodrick gerig het as volg vir die kindertjies in die konsentrasiekampe: "in the name of the little children whom I have watched suffer and die, and whom I cannot for a moment forget, I make bold to plead with you once more. In the name of our common humanity I urge that immediate steps may be taken by

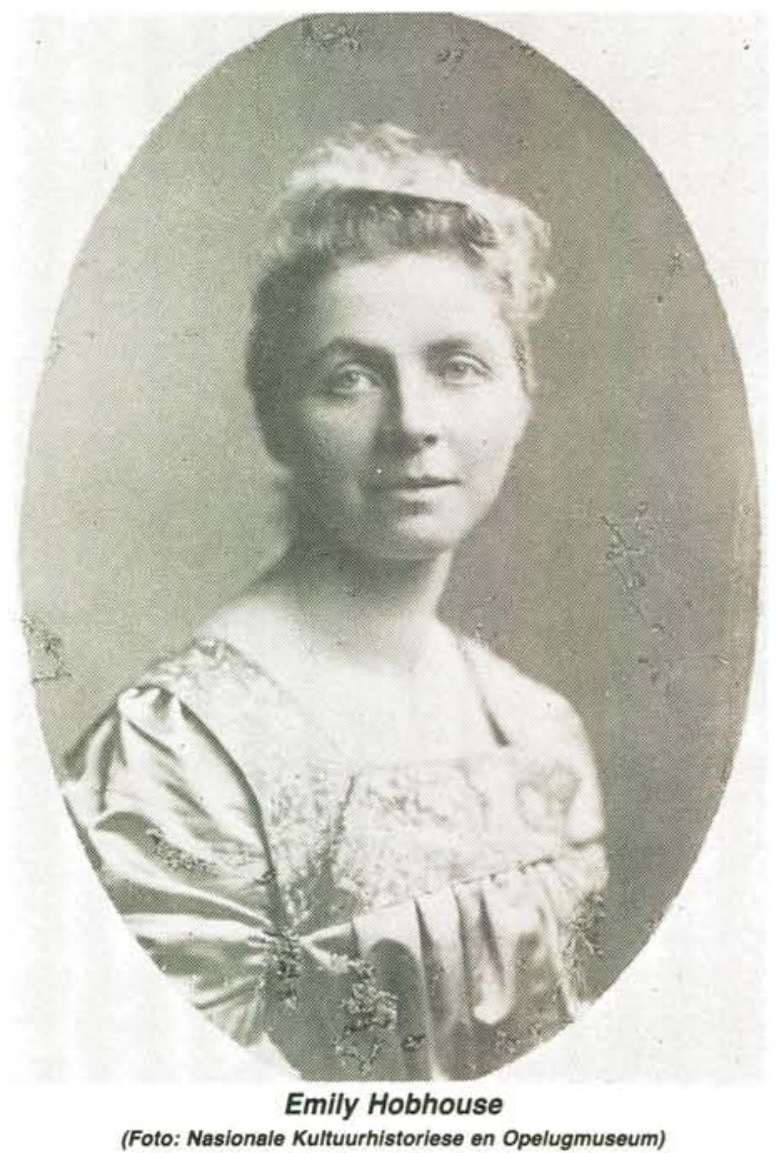

those qualified and empowered to act, lest one day we are bowed down by the humiliating and grievous thoughts that we have sat still and watched calmly the extermination of a race brave and strong enough to have kept the British Empire at bay for two long years. I need not recapitulate the proposals which I made to you, some of which you seemed to adopt, though, alas, even your adoption has appeared to be powerless to secure the effectual employment of the most important. I ask at least for effectual amelioration.

Yet is it not conceivable that we might go further? The men cannot end the war. The women will not end the war. Cannot the children help to bring about that peace which both sides so earnestly desire? Thousand have given their innocent lives. Thousands more are sick and like to die. Is it not enough? What the children need of proper food, clothing and shelter cannot be brought to them; transport is too difficult, supplies too scarce. They must die, die where we have placed them, in their hundreds and their thousands, unless the war ends and sets them free. 'The cry of the children' comes to us now not from our own mines and factories, but from across the seas. Will it be heard and answered? 
Will not your own and every parent's heart in England respond to their cry, and beat in sympathy with those mothers who have bravely borne the loss of homes and possessions, but stand aghast and enduringly resentful as they witness their children swept away? There are cases where women have entered camps with eight and ten children, and death has claimed them all. Do we want 'unconditional surrender' at the cost of so much child-life? Is it worth the price? For the men of either side I say nothing. They have chosen their part and must abide by it. For the women also I do not now plead; they are always strong to endure. But I do ask, in the name of the innocent and helpless children, that England's humanity triumph over her policy, so that the sacrifice of the children may be stayed. Is there a nation that will not honour her the more? In the earnest hope that you will listen to my appeal, - I have the honour to be,

Yours faithfully Emily Hobhouse." ${ }^{39}$

Alhoewel Emily Hobhouse so 'n smekende pleidooi ten behoewe van veral die kinders in die kampe gelewer het, en in weerwil van die kritiek van opposielede in die Britse Parlement, is daar nie veel gedoen om die lyding in die kampe te verlig en die sterfgevalle onder kinders te verminder nie. Die Britse owerheid het verwag dat met die aanbreek van die lenteweer die sterftesyfer ' $n$ daling sou toon. In teenstelling met hierdie verwagtings was die sterftesyfer in Oktober 1901 die hoogste en in die konsentrasiekampgeskiedenis staan Oktobermaand bekend as die "swart" maand. In die 17 Transvaalse kampe met ' $n$ bevolking van 57905 het die dood 1616 lewens geëis - 'n sterfte van 326 per duisend per jaar. Dit beteken dat indien die sterfte so sou voortduur die hele kampbevolking in die Transvaal oor ' $n$ periode van iets meer as drie jaar sou uitsterf. In die Vrystaatse kampe was die sterftesyfer nog hoër. Uit 'n kampbevolking van 45306 het 1514 die lewe gelaat, wat 'n sterftesyfer van 401 per duisend per jaar beteken het. In die Vrystaat was die sterftesyfer per duisend per jaar die hoogste in Brandfortkamp naamlik 1256 , gevolg deur Heilbron met 932 en Vredefortkamp met $518 .{ }^{40}$

Dit was die kindertjies wat dit weereens die meeste moes ontgeld. In die kampe te Mafeking, Standerton en Vryburg was die sterftesyfer vir Oktober onderskeidelik 1 737, 1855 en 1202 per duisend per jaar. Die gemiddelde kindersterfte vir Transvaalse kampe was 600 per duisend per jaar. Vir die ooreenstemmende periode, Oktober 1901, was die kindersterfte in die Vrystaatse kampe nog hoër naamlik 634 per duisend per jaar. Onrusbarend is dit om te dink dat as die kindersterfte in die Vrystaatse kampe teen die tempo van Oktobermaand 1901 sou voortduur, dit net een jaar en sewe maand sou neem voordat die hele kinderbevolking in laasgenoemde kampe gesterf het. ${ }^{41}$

Die geweldige hoë sterftesyfer vir Oktober 1901 het Groot-Brittanje genoop om drasties op te tree ten einde die hoë sterftesyfer tot ' $n$ laer peil te dwing. Vanuit Engeland is daar geneeshere, matrones en opgeleide verpleegsters na die Transvaalse en Vrystaatse kampe gestuur. Dit het tyd geneem om die nuwe maatreëls toe te pas en daarom kon die effektiewe uitwerking daarvan eers vanaf Januarie 1902 waargeneem word. Die dokters, matrones en verpleegsters wat van Engeland gekom het, het eers in Desember 1901 by die kampe diens aanvaar. Aan die einde van Desember was daar ten minste een dokter en min of meer twee verpleegsters vir elke duisend kampbewoners. Deur die toegewyde diens deur bekwame dokters en verpleegsters, het die sterftes in die kampe vanaf Januarie 1902 as volg gedaal:

\begin{tabular}{|c|c|c|}
\hline \multicolumn{2}{|c|}{$\begin{array}{l}\text { Transvaalse Kampe } \\
\text { (sterftes per } 1000 \text { p.j.) }\end{array}$} & $\begin{array}{c}\text { Vrystaatse Kampe } \\
\text { (sterftes per } 1000 \text { p.j. }\end{array}$ \\
\hline Januarie & 139 & 212,9 \\
\hline Februarie & 71 & 84 \\
\hline Maart & 44 & 52 \\
\hline April & 28 & 32 \\
\hline Mei & 19,5 & 24 \\
\hline
\end{tabular}

Die toestand in die kampe het so gebly tot die kampe na die vredesluiting op 31 Mei 1902 opgebreek is. ${ }^{42}$

In Maart 1902, kort voor die kampe verdwyn het, was die getal blankes in die konsentrasiekampe as volg:

\begin{tabular}{|c|r|r|r|}
\hline Provinsie & $\begin{array}{c}\text { Volwas- } \\
\text { senes }\end{array}$ & Kinders & Totaal \\
\hline Transvaal & 30208 & 22363 & 52571 \\
Vrystaat & 21474 & 16467 & 37941 \\
Natal & 11410 & 9311 & 20721 \\
Kaapkolonie & 80 & 195 & 275 \\
\hline Totaal & 63172 & 48336 & 111508 \\
\hline
\end{tabular}

As die wat reeds voor Maart 1902 in die kampe gesterf het in aanmerking geneem word, dan 


\section{SA Jeug en die SAW SA Youth and the SADF}

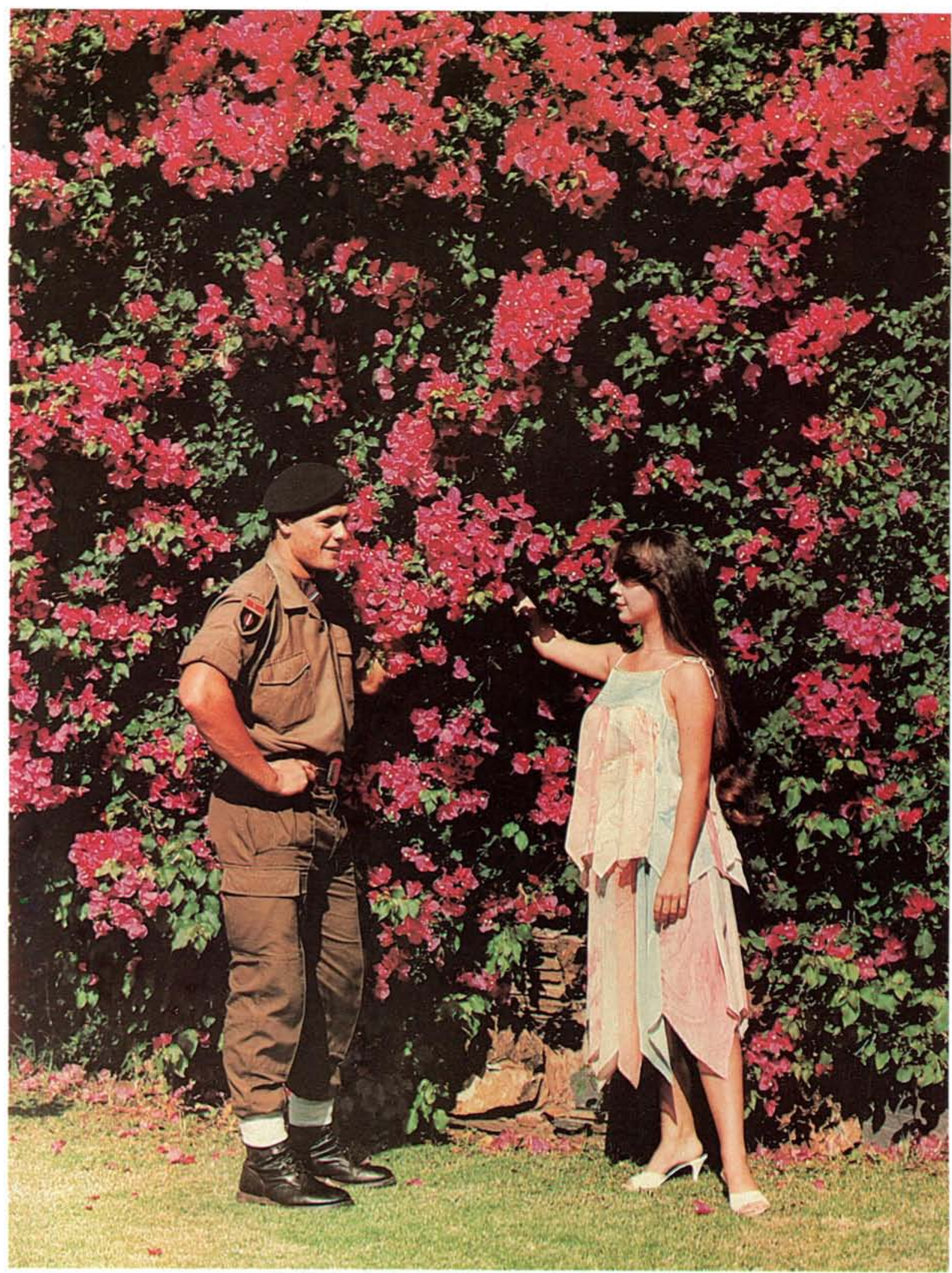




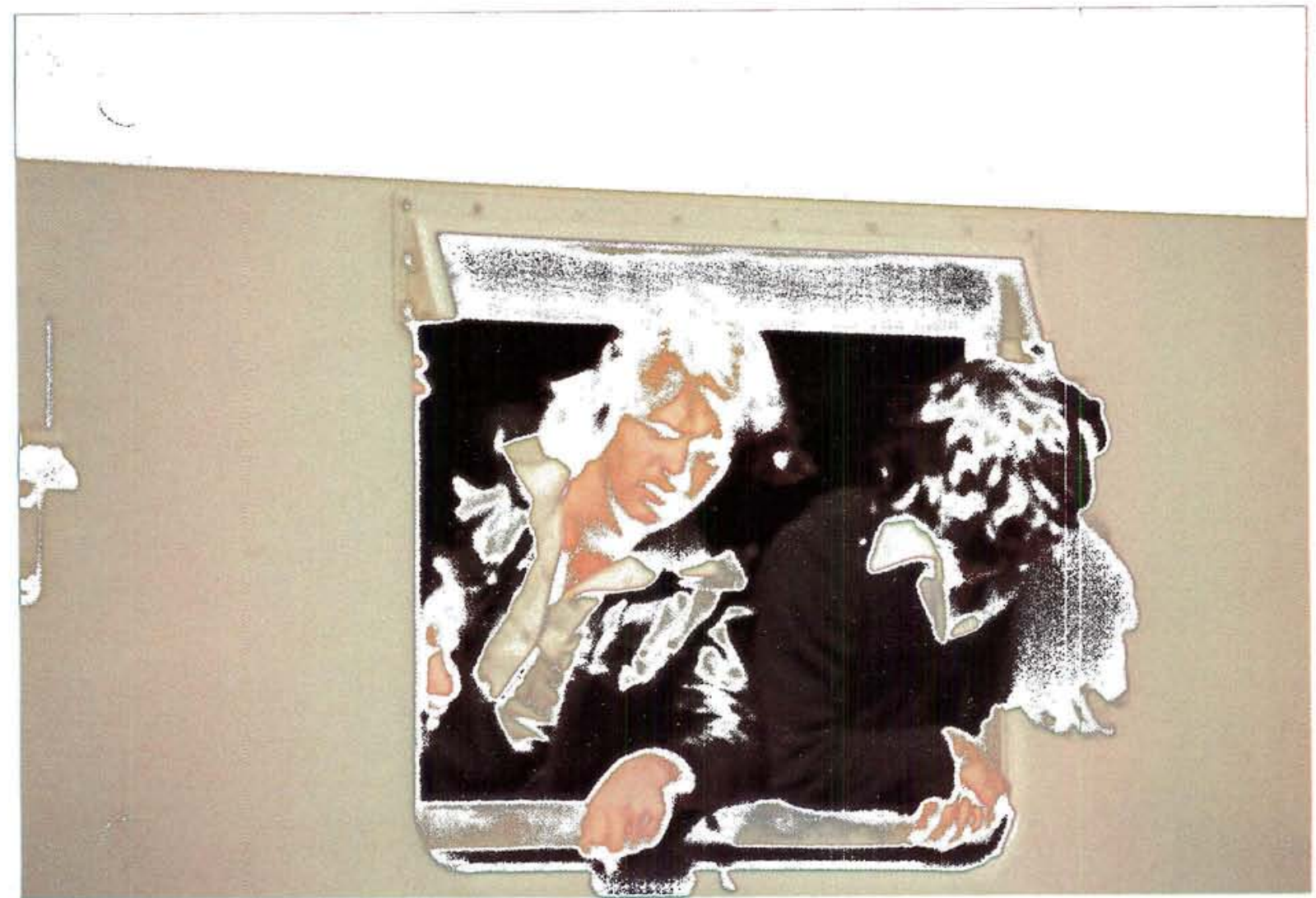

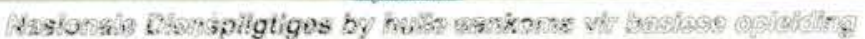

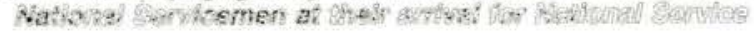

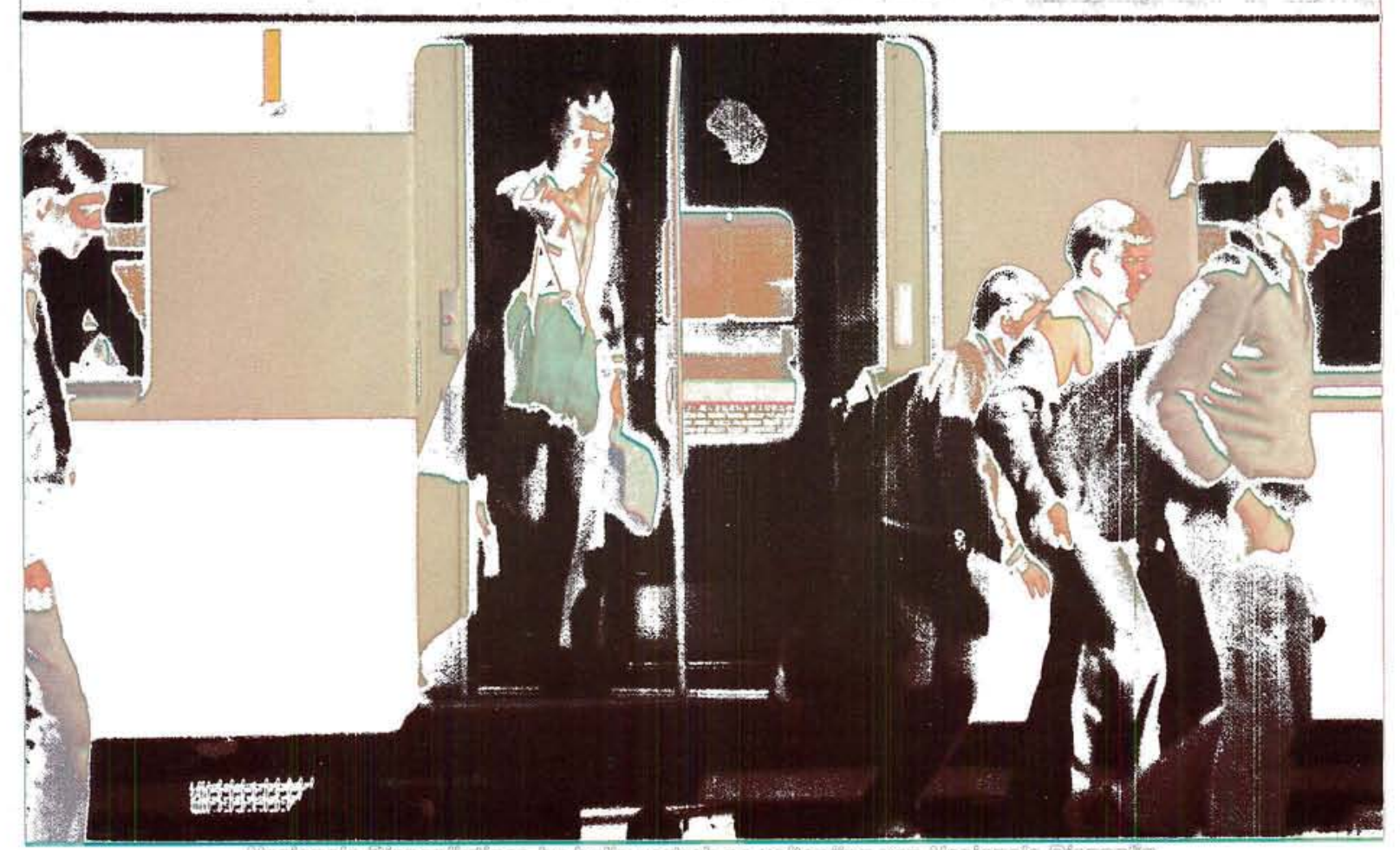

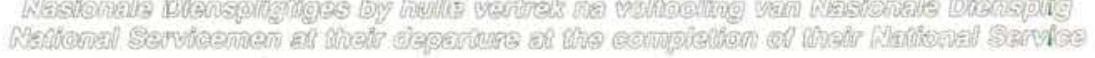



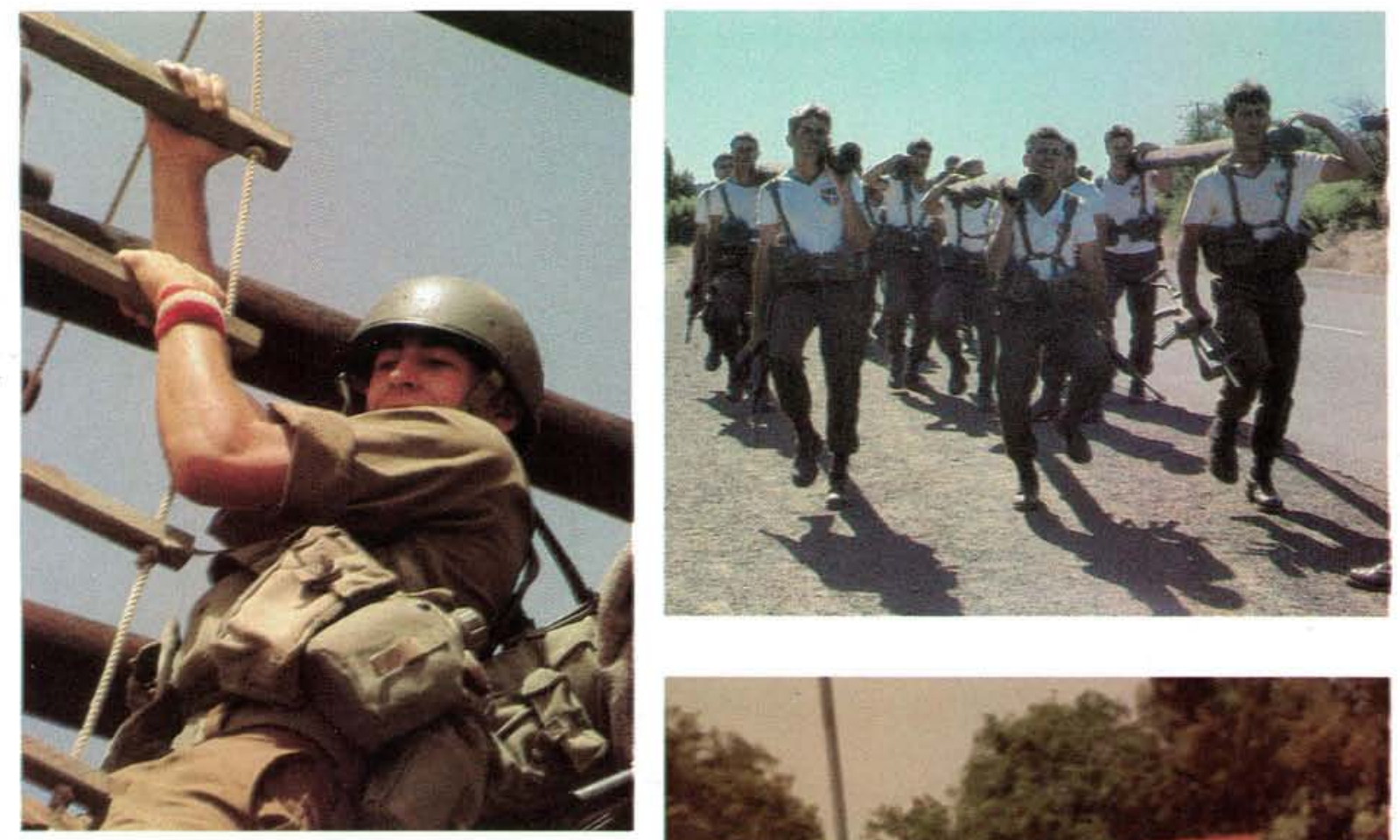

Nasionale Dienspligtiges en jongdames van die SAGD besig met basiese opleiding

National Servicemen and young women of the SAMS busy with basic training
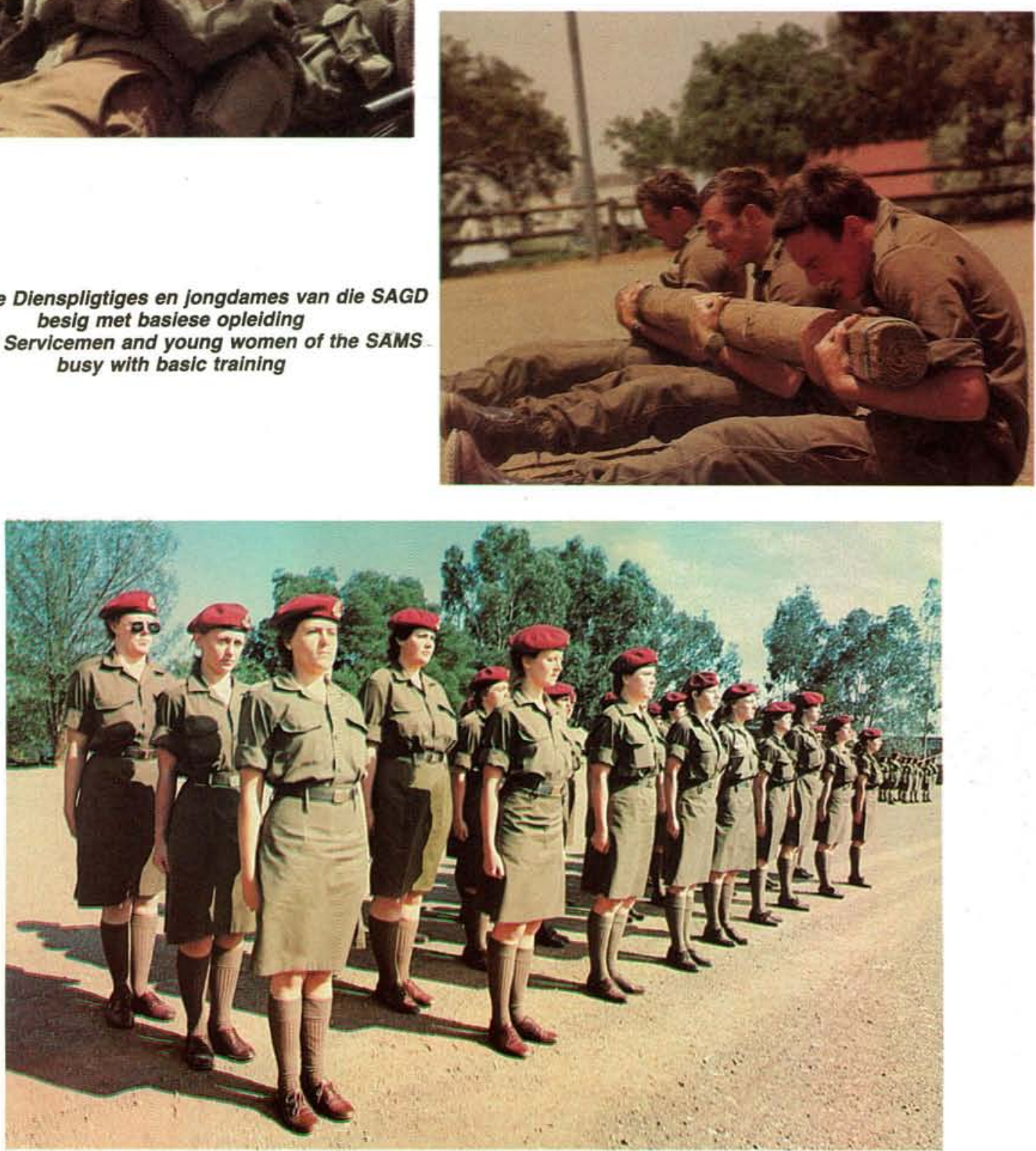


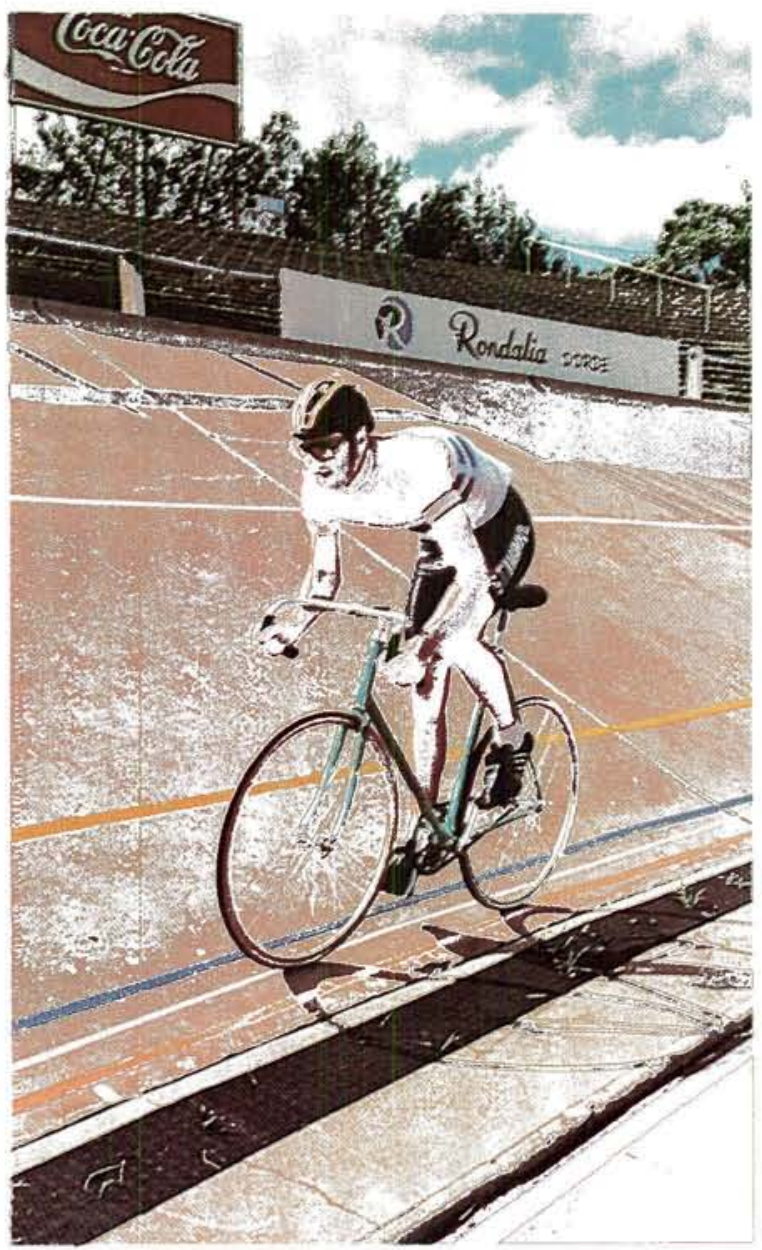

'n Fietsryer van die SAW besig om te oefen A Cyclist of the SADF busy training

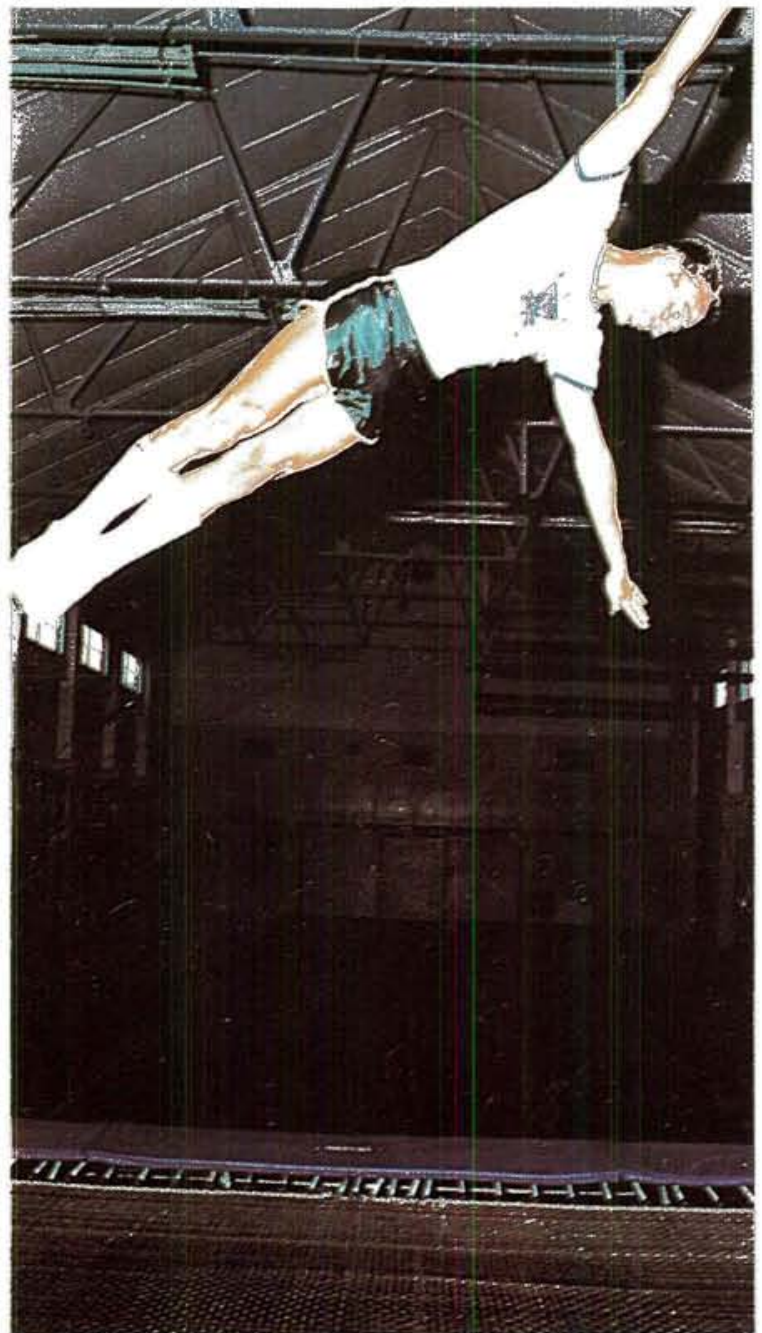

'n Trampolienspringer van die SAW vertoon sy vaardighede

A trampolinist of the SADF going through his paces

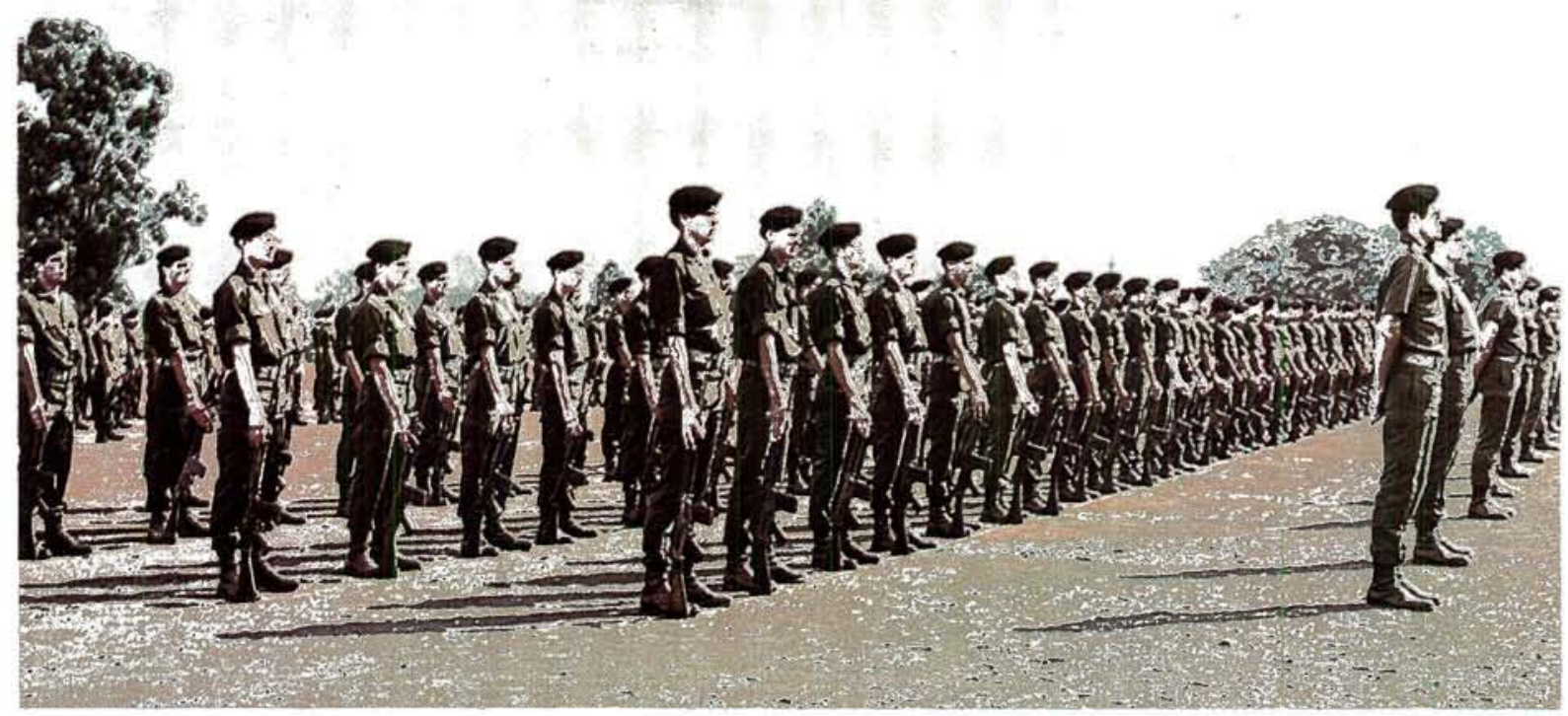

Nasionale Dienspligtiges op parade National Servicemen on parade 
moes daar veral heelwat meer kinders na die kampe gegaan het. ${ }^{43}$

Die volgende tabel toon die aantal mans, vrouens en kinders wat in die konsentrasiekampe gedurende die oorlog 1899-1902 beswyk het:

\begin{tabular}{|l|r|r|r|r|r|}
\hline & ZAR & OVS & KK & $\begin{array}{r}\text { Na- } \\
\text { tal }\end{array}$ & $\begin{array}{r}\text { To- } \\
\text { taal }\end{array}$ \\
\hline Mans bo 16 jaar & 814 & 785 & 74 & 3 & 1676 \\
Vrouens bo 16 jaar & 2030 & 2023 & 118 & 6 & 4177 \\
Kinders onder 16 jaar & 12900 & 8930 & 224 & 20 & 22074 \\
\hline Totaal & 15744 & 11738 & 416 & 29 & 27927 \\
\hline
\end{tabular}

Die oorlogsverliese aan burgers was as volg:

\begin{tabular}{|c|c|}
\hline $\begin{array}{l}\text { Gesneuwel } \\
\text { Gesterf aan siekte op kommando } \\
\text { Gedood ten gevolge van } \\
\text { ongelukke op kommando } \\
\text { Gesterf as krygsgevangenes }\end{array}$ & $\begin{array}{r}3990 \text { burgers } \\
924 \text { burgers } \\
157 \text { burgers } \\
1118 \text { burgers }\end{array}$ \\
\hline Totaal & 6189 burgers \\
\hline
\end{tabular}

Bogenoemde syfers stel die lot van die stryders en nie-stryders teenoor mekaar. Dit sal dadelik opgemerk word dat daar ongeveer vier en 'n half keer meer vroue en kinders omgekom het as wat daar manne in die veld deur die swaard of siekte beswyk het. Die afleiding wat gemaak kan word is dat dit veiliger in die gevegslinie was as in die konsentrasiekampe. ${ }^{44}$

Gelukkig het die sterftesyfer in die kampe vanaf Januarie 1902 begin afneem en moet dit toegeskrywe word aan die volgende naamlik die stappe deur die Britse owerhede geneem om die sterftes omlaag te dwing deur die kampe van ' $n$ veel doeltreffender mediese diens te voorsien soos meer dokters en opgeleide verpleegsters; die medici was oordeelkundig tussen die verskillende kampe verdeel byvoorbeeld by Bethulie waar ingewandskoors straf onder die 4255 inwoners voorgekom het, was ses medici, sewe verpleegsters, twee aptekers en drie matrones geplaas; beter behuising by hospitale met die nodige apparaat toegerus; verkleining van kampe deur die verplasing van kampbewoners vanaf die groter kampe na kampe in Natal en die Kaapkolonie (kleiner kampe is beter beheer, was naby die hawens en voorrade kon makliker voorsien word, 'n warmer klimaat veral in die winter en hierdie kampe was op geskikter terreine as die van Transvaal en die Vrystaat opgerig); die hervormings en verbeterings wat as gevolg van die werksaamhede en bemoeiings van die Dameskomitee aangebring is soos meer voedsame voedsel, genoeg vuurmaakhout, sopkombuise, beter huisvesting, doeltreffender latrines, beter watervoorsiening, ensovoorts. ${ }^{45}$

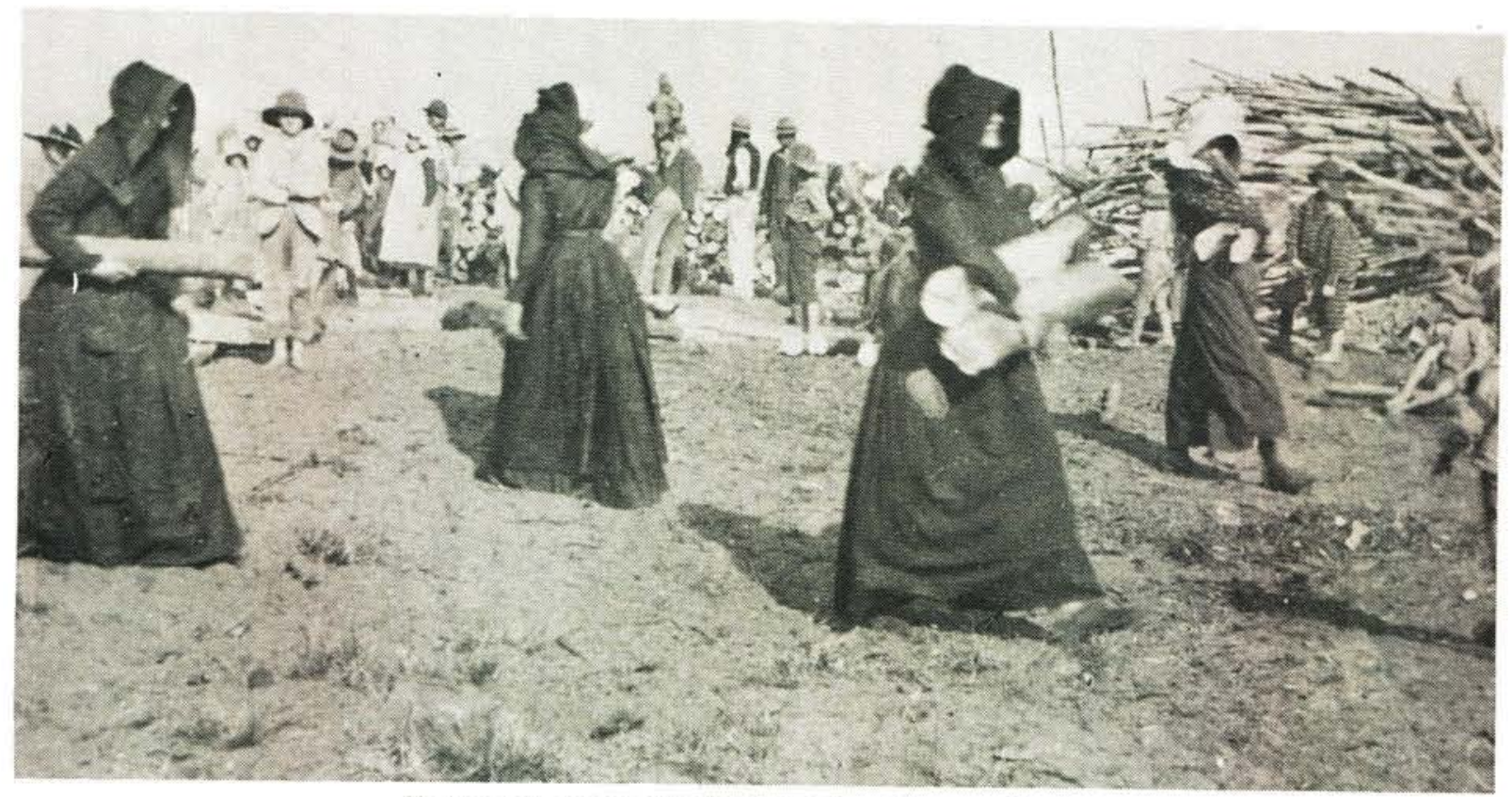

Vuurmaakhout word in die konsentrasiekampe uitgedeel (Foto: Nasionale Kultuurhistoriese en Opelugmuseum) 
Dat die sterftesyfer in die kampe na al die hervormings so gou afgeneem het, weerlê al die beskuldigings dat die inwoners van die kampe self vir die sterftes verantwoordelik was omdat hulle dan so vuil en onsindelik van aard sou gewees het. Nog ' $n$ rede vir die vermindering in sterfgevalle was dat die swakkes; verhongerdes en vermaerdes reeds gesterf het. Sedert die begin van 1902 was daar maar min babas onder die ouderdom van een jaar in die kampe oor en dit was juis hierdie groep wat gedurende die voorafgaande maande die meeste gesterwe het. Die wat die ontberings van die konsentrasiekampe oorleef het, was sterk genoeg om met die beter behandeling gou te herstel. Dit is te betreur dat die toestande in die konsentrasiekampe eers verbeter is nadat so baie kinders, vrouens en grysaards te sterwe gekom het. ${ }^{46}$

Die konsentrasiekampskole, waarin daar vir agtien maande gemiddeld by die 20000 Afrikanerkinders onderwys ontvang het, was nie baie ge- slaagd nie, maar dit het tog 'n positiewe uitwerking gehad. Alhoewel die onderrig elementêr was, het baie kinders tog die geleentheid gekry om ' $n$ tydlank skool te gaan. Kinders is konstruktief besig gehou waar hulle andersins vir kwaadgeld sou rondloop. Die kennis opgedoen, het by baie die begeerte laat ontstaan om verder te leer. Die bietjie Engels wat hulle geleer het, sou handig te pas kom in hulle latere lewe en vir baie was dit ' $n$ goeie fondament om die taal aan te leer. Swak gekwalifiseerde onderwyseresse het onder die leiding van bekwame en simpatieke hoofde baie geleer en verskeie het ná die oorlog na onderwyserskolleges gegaan om hul kwalifikasies te verbeter. Die tydperk wat kinders die Engelsgeoriënteerde skole besoek het, (veral onder die invloed van die Engelse onderwyseresse) het ' $n$ blywende invloed ten gunste van die Engelse kultuurgoedere en taal op hulle uitgeoefen. Sommige van die onderwyser(esse) het ' $n$ verfynde invloed op die kinders gehad veral waar hulle saam met die kampkinders na die plase gegaan het om daar onderwys te gee.

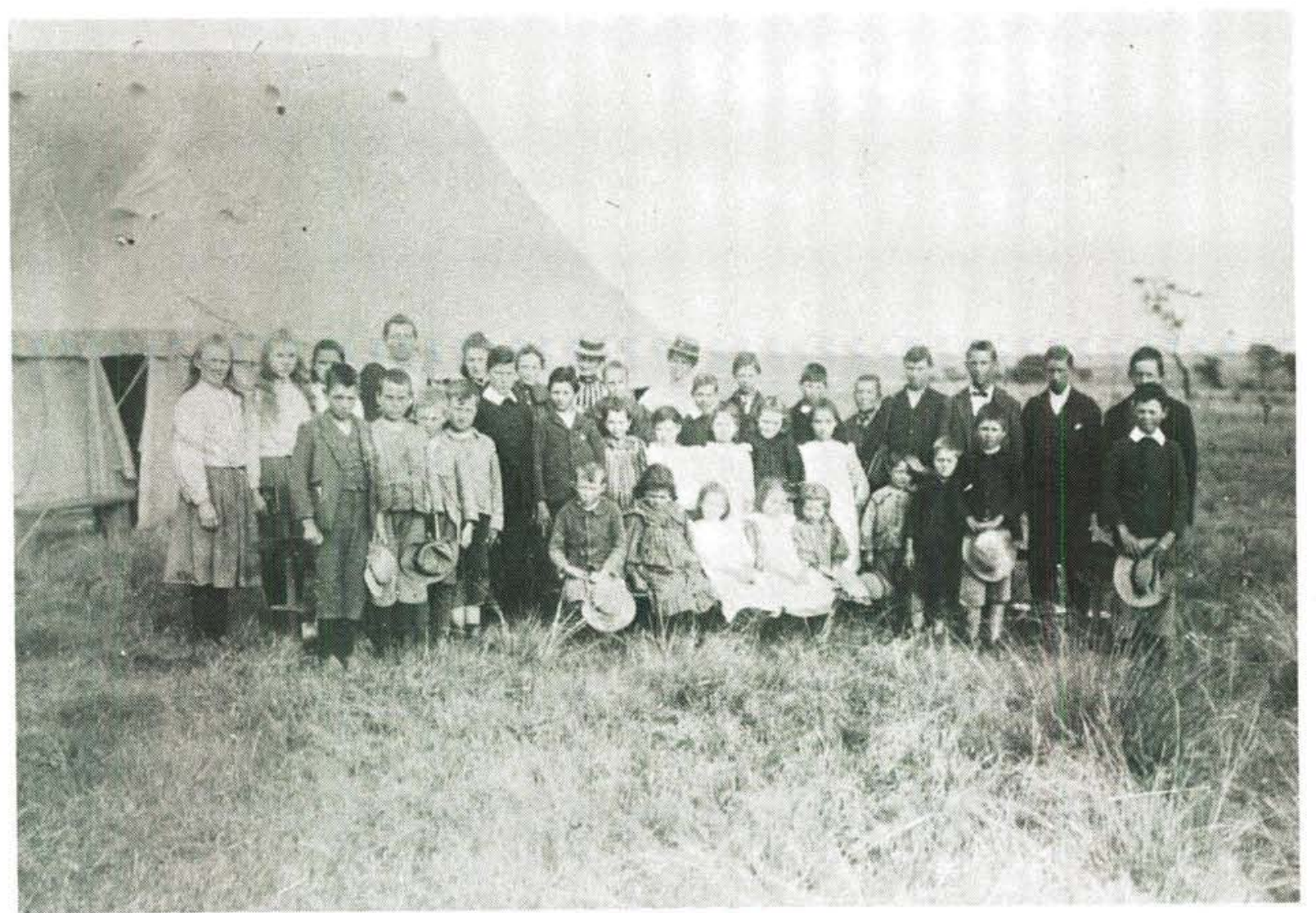

Konsentrasiekampskool te Irene

(Foto: Nasionale Kultuurhistoriese en Opelugmuseum) 
$\mathrm{Na}$ die oorlog is die anglisasie van die skole en die land wel deur die kampskole vergemaklik: 'n volledige onderwysdepartement is gedurende die oorlog georganiseer wat ná die oorlog net kon voortgaan. Die beleid van verengelsing in Suid-Afrikaanse skole het daarteenoor ook opnuut ' $n$ taalbewustheid by die Afrikaanssprekendes laat posvat. Uit hierdie taalbewustheid is die verset teen totale verengelsing gebore en dit sou help om die grondslag vir die ontwikkeling van Afrikaans tot landstaal te lê.

Nieteenstaande al die dinge wat vir of teen die kampskole ingebring mag word, een ding staan vas, en dit is dat die kampskool ' $n$ ligpunt vorm in ' $n$ andersins donker tydperk van ons geskiedenis. ${ }^{47}$

\section{Penkoppe te velde en as krygsgevangenes}

Met die uitbreek van die Tweede Vryheidsoorlog in 1899 is alle weerbare mans in die Suid-Afrikaanse Republiek en die Republiek van die Oranje-Vrystaat opgekommandeer. Om 'n burger van die land te word, moes jy die ouderdom van 16 jaar bereik het. Almal wat opgeroep was om hulle land te verdedig was 16 jaar en ouer. Baie van die seuns wat nog nie die ouderdom van 16 bereik het nie, kon op eie risiko aansluit. Van die seuns onder 16 jaar het op die plase agtergebly en was hulle moeders behulpsaam met die boerdery. Toe die vrouens en kinders later na die konsentrasiekampe weggevoer is, het sommige van hierdie jong seuns, algemeen bekend as penkoppe, ontvlug en by die Boerekommando's aangesluit. Seuns wat op hierdie wyse aangesluit het, was baie jonk, sommiges was skaars 10 of 12 jaar oud. Van die Penkoppe was so jonk dat hulle nog nie aan gevegte kon deelneem nie maar het tog baie nuttige werk gedoen deur die kommando se slagvee op te pas of om tydens gevegte na die perde om te sien. Gedurende die oorlog is ' $n$ groot hoeveelheid van die Penkoppe gevange geneem en in ballingskap weggestuur. ${ }^{48}$

Alle seuns onder die ouderdom van sestien jaar wat tydens die Tweede Vryheidsoorlog op kommando was, word Penkoppe genoem. Daar bestaan verskil van mening oor die oorsprong van die woord Penkop. Die een verklaring is dat die Boere van 'n wildebeesbulletjie waarvan die horings skaars uit was en soos twee penne gestaan het, as 'n Penkop gepraat het. Om hierdie

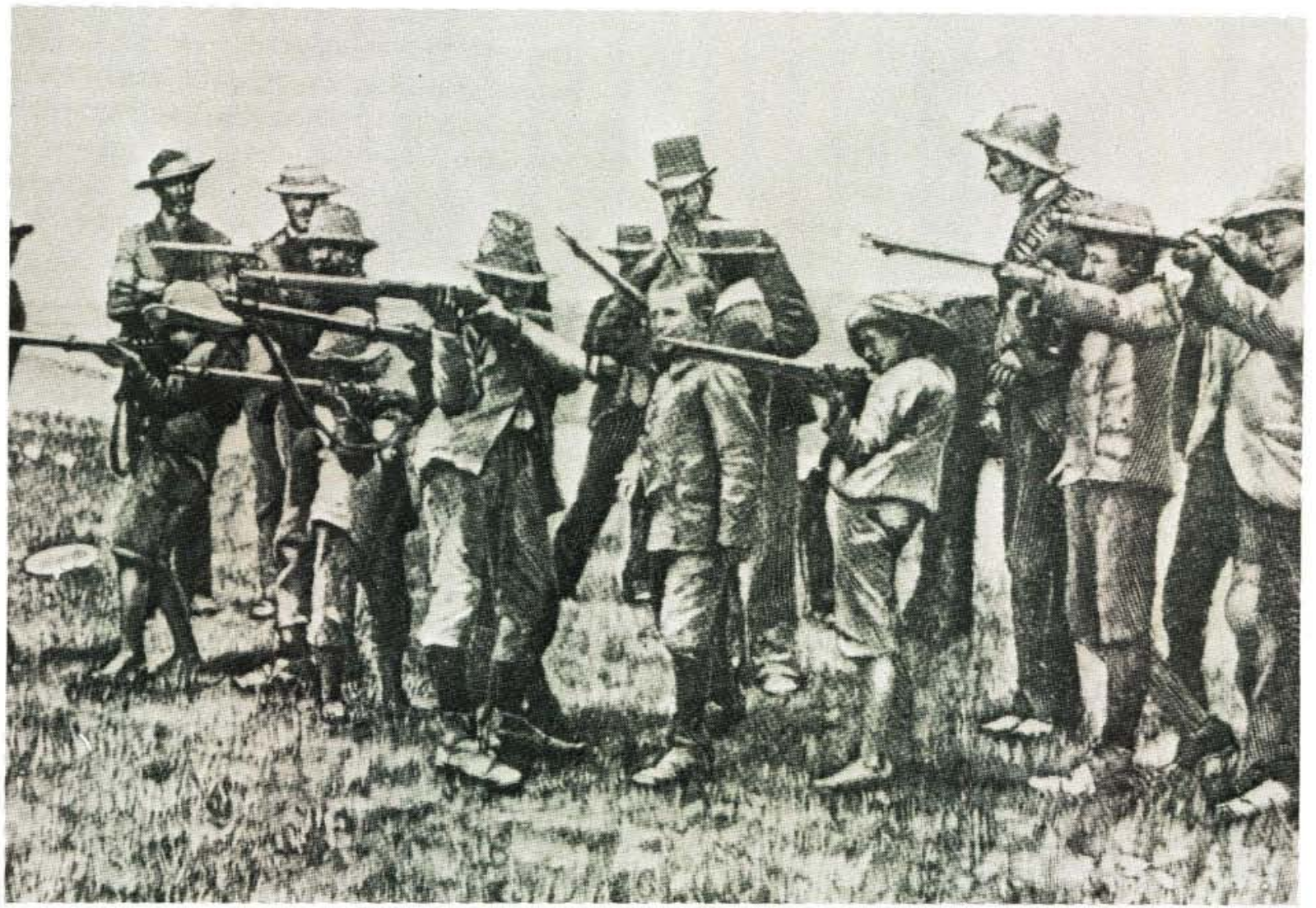

Boerseuns besig om deel te neem aan 'n skietoefening 
rede is ' $n$ energieke jong seun wat baie soos ' $n$ jong wildebees opgetree het, 'n Penkop genoem. Die ander verklaring is dat volwasse mans destyds hulle hare taamlik lank gedra het, terwyl die seuns se hare met 'n knipper kort geskeer is. Hulle hare het as gevolg van die kortheid regop gestaan, soos ystervarkpenne, en daarom is hulle Penkoppe genoem. ${ }^{49}$

Elke Penkop het sy eie perd gehad en die ouer Penkoppe het ook gewere besit. Op kommando is daar geen verskil tussen Penkoppe en gewone burgers gemaak nie. Hierdie Penkoppe was dikwels van die beste krygsmanne. Hulle was jonk en energiek, in gevegte was hulle waaghalsig, onverskrokke en dapper en selde mismoedig. So het Generaal de Wet erken dat hulle van sy beste krygsmanne was en dat hy altyd op sy Penkoppe kon staatmaak. Die Penkoppe onder bevel van kaptein (later kommandant) Gideon Scheepers het vir hom waardevolle verkenningswerk gedoen. ${ }^{50}$

Generaal de Wet het die taktiek gevolg om sy laer, sodra hy inligting oor die vyand van sy verkenners Danie Theron en Gideon Scheepers ontvang het, so onopsigtelik as moontlik gedu- rende die nag na 'n veiliger plek te verskuif. Bedags is daar dan brandwagte rondom die laer uitgesit. Hierdie brandwagte is teen die middag afgelos en die nuwe wagte moes tot na sononder op hul poste bly en dan weer by die laer terugrapporteer. Indien bevind word dat dit daar nie meer veilig was nie, het die laer, sodra dit donker was, na ' $n$ veiliger plek vertrek. ${ }^{51}$

Jan van Kaller het as ' $n$ knaap van veertien of vyftien jaar oud by die kommando aangesluit. Op 'n sekere dag is hy saam met Koos de Bruyn as brandwag uitgesit. Hulle moes brandwag staan op ' $n$ koppie in die omgewing van die dorpie Senekal wat toe reeds in Engelse hande was. Koos de Bruyn was 'n man van oor die twintig jaar oud. 'n Endjie van die koppie, in die rigting van Senekal, het die Cronje's gewoon. Teen die middag besluit Koos en Jan om na die plaas van die Cronje's te ry om daar ' $n$ bietjie met die nooientjies te gesels. Hulle optrede was 'n oortreding maar hulle het gereken dat hulle nie uitgevind sou word nie. Daar aangekom het hulle lekker gekuier totdat ' $n$ klompie Engelse perderuiters hulle verskyning gemaak het. Hulle wou dadelik op die Engelse vuur maar die huisbaas het by hulle gepleit om dit nie te doen nie,

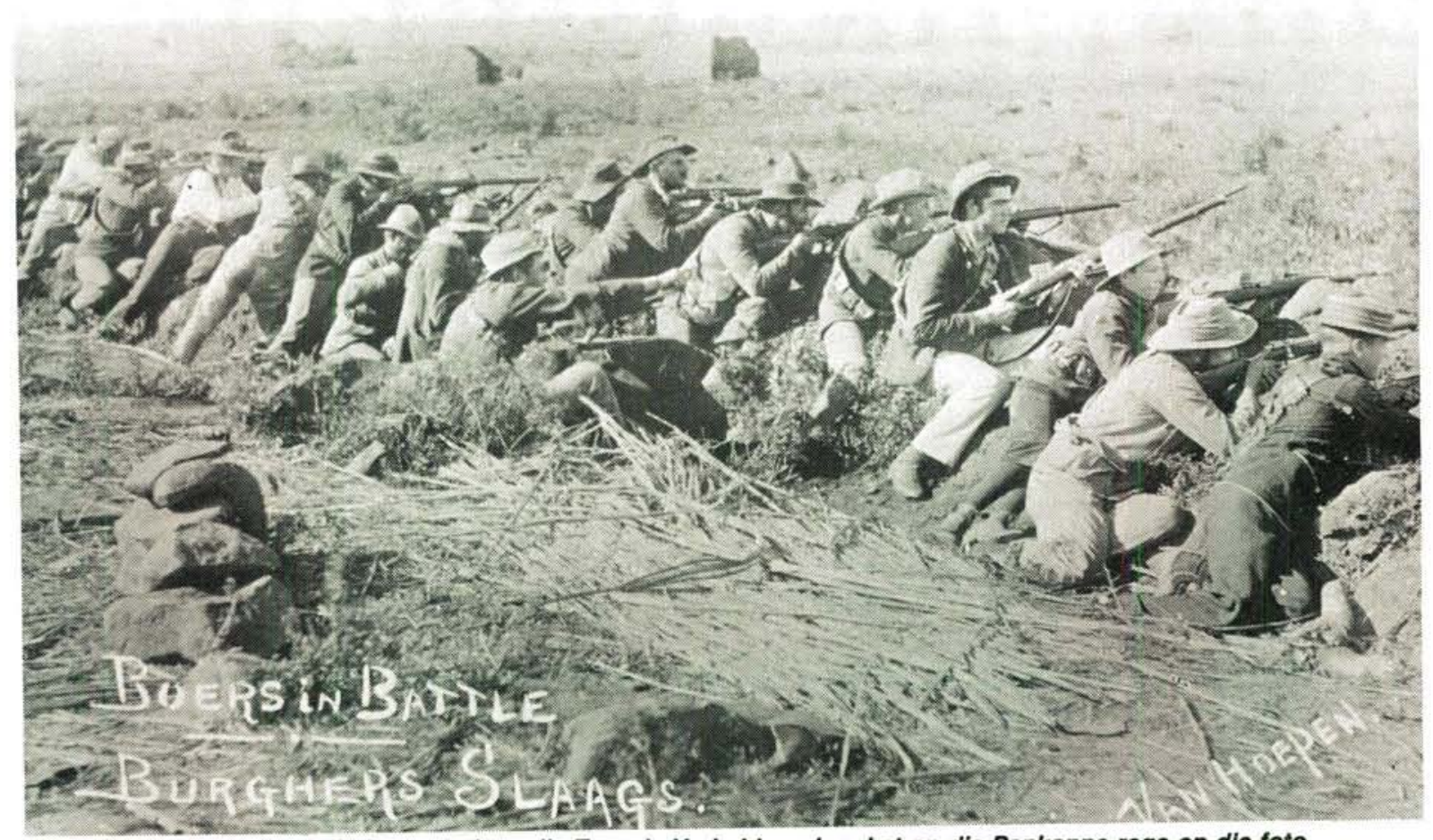

'n Veglinie van die Boere tydens die Tweede Vryheidsoorlog. Let op die Penkoppe regs op die foto. 


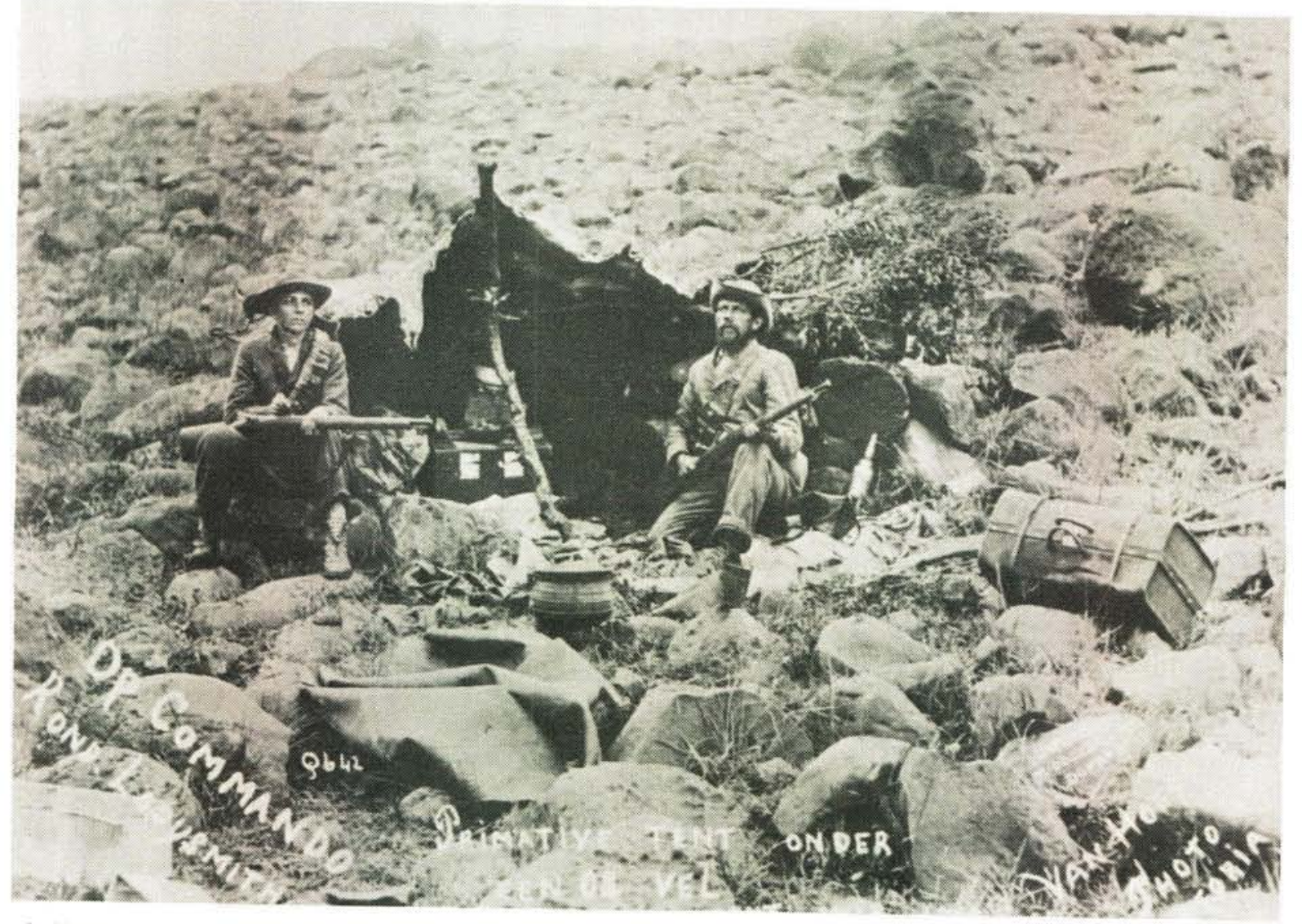

'n Voorpos van dle Boere tydens die Tweede Vryheidsoorlog. Links voor dle primitiewe beesveltent sit 'n Penkop.

omdat hy bevrees was dat die Engelse sou reken dat hy die Boere goedgesind was en dat hulle straks al sy goed sou konfiskeer en hom selfs kon verban. ${ }^{52}$

Tussen die huis en 'n digte kwerperlaning was daar ' $n$ klipmuur van 'n paar voet hoog. Koos en Jan het posisie agter die kweperlaning ingeneem. Die Engelse het nie geweet hoeveel Boere daar was nie en het agter die huis skuiling gesoek. Toe hulle gewaar dat daar nie meer Boere binne die huis is nie, het hulle by die agterkant van die huis ingegaan en van daar op die Boere in die tuin geskiet. Om die indruk te skep dat daar heelwat Boere was, het Koos en Jan van plek tot plek agter die kweperlaning en muur beweeg en vanuit verskillende posisies op die Engelse gevuur. Koos het sy kop te hoog bo die klipmuur uitgesteek en 'n koeël van die vyand het hom skrams bokant die oor getref. Die wond was diep en het baie gebloei sodat Koos sy bewussyn verloor het. Jan het gereken dat Koos dood is maar het aangehou om te skiet en nooit aan oorgee gedink nie. Later toe Koos sy bewussyn herwin, het hy sy hand opgesteek as ' $n$ teken dat hy oorgee en het hy na die huis gekruip om verpleeg te word..$^{53}$
Sy wond is deur die huismense verbind en toe die Engelse hom vra hoeveel Boere in die tuin is, het hy geantwoord dat daar tien is. Toe dit donker word het al die Engelse behalwe die vyf gewondes waaronder ' $n$ Afrikaner was wat aan Britse kant geveg het, weggery om versterkings te gaan haal. Een van die meisies het versigtig uit die huis gesluip en aan Jan gaan vertel dat daar nog net gewondes in die huis is en dat die Engelse na die dorp gery het om versterkings en 'n ambulans te gaan haal. Hierop het Jan na die huis gegaan, 'n paar woorde met Koos gewissel, die vyf gewondes se gewere en perde geneem en daarmee na die Boerelaer afgesit. Die perde het hy aanmekaar vasgeknoop en hulle voor hom uitgejaag. ${ }^{54}$

Toe Koos en Jan nie op die bestemde tyd opdaag nie, het die burgers van Generaal de Wet se kommando onrustig geraak en na hulle gaan soek. Die kommandomense kon hulle nie vind nie. Skielik het hulle ' $n$ ruiter gewaar wat na hulle aangejaag kom, dit was Jan van Kaller. Nadat hy sy verhaal aan hulle meegedeel het, is ' $n$ sterk patrollie en ' $n$ kar gestuur om Koos te gaan haal. Hulle het Koos in die huis gekry en na die laer teruggebring. Later is van die Cronje's ver- 
neem dat hulle net betyds was want ' $n$ paar minute later het die Engelse met versterkings by die huis opgedaag. Toe aan Jan die vraag gestel is waarom hy nie ' $n$ plan gemaak het om weg te kom nie, was sy antwoord dat hy die Engelse besig gehou het sodat hulle nie kon wegkom om op die Boerelaer te spioeneer en dit aan te val nie. Hy het gevoel dat dit sy plig was en sou desnoods tot die dood veg om die laer te beskerm. ${ }^{55}$

Baie ander Penkoppe was nie so gelukkig om met hulle lewe daarvan af te kom nie, maar het of hul lewe op die slagveld gelaat of is deur die Engelse gevange geneem en as krygsgevangenes weggestuur. 'n Penkop wat sy hoogste offer aan sy vaderland gebring het, was Piet van Rooyen. Hy was maar ' $n$ knaap van dertien jaar toe hy by die kommando aangesluit het. Teen die vyfde of sesde Februarie 1901 sou die Boerekommando naby Trompsburg oor die treinspoor gaan. Hulle het hulle egter die nag in 'n gepantserde trein vasgeloop en na 'n hewige geveg het die meeste van die Boere hul perde in die hande gekry en na veiligheid gejaag. Toe dit dag word, het die burgers gemerk dat Piet se perd daar is maar hyself was nêrens te bespeur nie. Daar was bloed aan die saal en daarvan het hulle afgelei dat hy gewond is. Terwyl daar planne beraam is om met ' $n$ wit vlag na die Engelse te gaan om vas te stel wat met Piet gebeur het, het ' $n$ ruiter van ' $n$ ander kommando daar opgedaag en hulle die verhaal van die treurige einde van Piet meegedeel. Piet was swaar gewond en toe hy hom wou help, het Piet hom vertel wie hy is en hom versoek om homself te red. Piet was heeltemal tevrede om te sterf vir sy vaderland. Piet se ouers het later van die Engelse verneem dat hul hom swaar gewond in die veld gevind het. Hulle het hom met 'n ambulans na ' $n$ veldhospitaal geneem maar op pad daarheen het hy gesterf. Hulle het hom toe langs die pad begrawe. ${ }^{56}$

Al die Penkoppe was egter nie so gelukkig soos Niklaas Kriek nie. Hy was maar twaalf jaar oud toe hy saam met sy vader op kommando gegaan het. Toe kommandant Marthinus Prinsloo hom op 29 Julie 1900 by die Rooiberge, suid van Bethlehem, met vyfduisend man oorgegee het, is Niklaas en sy vader albei gevang. Sy vader is as krygsgevangene weggestuur maar toe die Engelse sien dat Niklaas nie eers ' $n$ geweer het nie, het hulle hom vrygelaat om na sy moeder op die plaas te gaan. 'n Paar maande later het Niklaas weer by een van die kom- mando's aangesluit en tot die einde van die oorlog dapper saamgeveg. ${ }^{57}$

Nadat die vrouens en kinders na die konsentrasiekampe weggevoer is en die plaashuise, vee en graan verwoes is, het dit vir die Boere op kommando al moeiliker geword om kos en klere in die hande te kry. Later het baie burgers die klere van Britse soldate wat doodgeskiet is, vir hulle geneem. In sommige gevalle het die burgers Engelse soldate gevang, hulle "geskud", dit beteken die Engelse soldate moes van hulle klere uittrek sodat die Boere dit kon neem. Dit het dan die Engelse soldate vrygestaan om die ou en verslete klere van die burgers aan te trek om oor die weg te kom tot tyd en wyl hulle weer by hul kolonnes aansluit. Dit was egter verbode vir enige persoon, wat nie ' $n$ Britse soldaat was nie, om ' $n$ Kakie-uniform te dra. As ' $n$ burger met 'n Kakie-uniform gevang is, kon hy ter dood veroordeel word. Ernst de Jager, ' $n$ twaalfjarige Penkop, het toe sy klere gedaan was ook 'n Britse soldaat se uniform vir hom toegeëien. Op dertienjarige ouderdom is hy in die distrik Reddersburg deur die Engelse gevange geneem. Omdat hy ' $n$ Kakie-uniform aangehad het, is hy ter dood veroordeel. Hy moes sy eie graf grawe en sou die volgende oggend tereggestel word. Daardie nag is hy onder strenge bewaking geplaas. Hy het egter daarin geslaag om te ontsnap, deur die blokhuislyn te glip, bedags skuiling te soek en te slaap en snags voort te vlug van plaas tot plaas. So het hy uiteindelik, na 'n aantal noue ontkomings, by sy moeder in die konsentrasiekamp te Bethulie uitgekom. Alhoewel sy naam eintlik Ernst was, was hy beter bekend onder sy noemnaam Jimmie. Die volgende dag het hy hom by die kampowerheid aangemeld onder die naam van Jimmie de Jager. $\mathrm{Na}$ lang ondervragings en oorwegings is hy as krygsgevangene na St Helena gestuur waar hy as banneling moes bly tot die oorlog verby was. ${ }^{58}$

In die Huisgenoot van 22 Januarie 1943 stel veldkornet E.F. Röhm die saak van die Penkoppe as volg: "omdat hul gedagtenis nie vergeet word nie - kinders wat as te jonk beskou is om op kommando te gaan, maar wat weggeloop het van plase, uit kampe en uit Basoetoland om die vrye veld, waar hulle gebore is, vry te hou; wat so dapper geveg het soos die beste generaals, al is hul name nooit in die geskiedenis gemeld nie; wat in hegte kameraadskap gesnoer is deur die doodsgevaar wat hul daagliks trotseer het sonder gedagte aan beloning of onderskeiding - aan hulle bring ek, hul veldkor- 
net, hulde deur 'n paar van die insidente, wat ons saam deurleef het, te beskryf." ${ }^{59}$

So vertel veldkornet Röhm van 'n sekere Rooi Flip Snyman by wie daar aan moed en durf geen einde was nie. Hy was een van drie neefs, almal het dieselfde voorname gehad tewete Vaal-Flip Snyman en Flip Geerling. In 1901 het Kitchener 'n proklamasie uitgevaardig waarin hy bepaal het dat almal wat hul nie voor 'n vasgestelde datum oorgee nie, sou verban of tereggestel word en al hul besittings sou gekonfiskeer of vernietig word. Net na bogenoemde proklamasie het die volgende insident plaasgevind naamlik in 'n geveg met die gekombineerde burger-polisieposte het Penkoppe met die Tommies handgemeen geraak. Terwyl Rooi Flip besig was om voetgangers te ontwapen en ver agter sy maats geraak het, het een van die ontwapende Tommies hom gepak en styf vasgehou sodat hy nie sy geweer kon gebruik nie. Gou was ' $n$ tweede Tommie by wat Flip al in sy gesig met sy bajonet gesteek het. Die derde Tommie het, wanneer die kans hom voordoen, na Flip geskiet. Vir ' $n$ ander persoon sou die haglike posisie waarin hy hom bevind het, seker noodlottig gewees het, maar nie vir Rooi Flip nie. Met 'n uiterste kraginspanning het hy hom van die greep van die Tommie losgeruk en toe trek hy gelyktydig die skoot uit sy oorgehaalde geweer op die Tommie af. Die bajonetsteker het volgende aan die beurt gekom en toe Rooi Flip hom omdraai om met die derde Tommie af te reken, het die alreeds met sy hande in die lug gestaan. Agt dae later het Rooi Flip met verbande om sy kop aan die slag van Slangfontein deelgeneem. ${ }^{60}$

Die volgende word deur voldkornet Röhm verte! van ' $n$ Penkop wat 'n uitstekende spioen geword het. Dit was ' $n$ ene Thys van Tonder. Thys se grootste begeerte was om een van die lang verkykers wat deur die Engelse offisiere gebruik is, te besit. Op ' $n$ keer is daar drie van die verkykers gebuit en Thys het so gesoebat dat hulle een aan hom gegee het. Vanaf daardie dag het hy verkenningswerk gedoen. Sy bruin merrietjie se stert het hy kort geknip sodat dié op ' $n$ afstand soos ' $n$ Engelse perd gelyk het. Hy het ' $n$ knap stukkie werk gedoen toe hy en twee ander brandwagte op ' $n$ koppie naby Springfontein verkenningswerk moes doen. Na 'n rukkie merk hulle 'n muilwa, gelaai met voer en agt-en-dertig Tommies daarop, wat van Springfontein kom. Hulle besef dadelik dat so ' $n$ muilwa met twaalf muile baie handig op kommando gebruik kan word. Thys het homself na die leegte gehaas waar hy hom in 'n sloot langs die treinspoor versteek het. Toe die wa verbykom, spring hy uit die sloot en halt hulle. Hy vertel aan die Tommies dat indien hulle sou weier om oor te gee, hy verplig sou wees om die kanonne, wat in die nabygeleë koppies opgestel is, op hulle af te vuur. Nadat die Tommies oorgegee het, trek hy al die geweerslotte uit en gooi dit op die wa. Die kleurlingdrywers moes die wa na die "Boeremagte" op die koppie dryf terwyl die ontwapende Tommies vooraan in gelid stap. Toe hulle by die ander twee brandwagte kom, word hulle plegtig voorgestel en beveel om na Springfontein terug te stap. Lank daarna is daar nog met vrug gebruik gemaak van die wa en muile om nie eens te praat hoe welkom die gewere en ammunisie was nie. ${ }^{61}$

As gevolg van die mannekragprobleem in die Republikeinse magte en die vyand se getalsoormag, het vrywilligers in haas alle ouderdomsgroepe die wapen opgeneem. Hierdie vrywilligers het bestaan uit jong penkoppe, skaars ouer as agt jaar en grysaards so oud as 75 jaar. Ongeag van die feit dat hulle nie dienspligtig was nie, het hulle genoeg moed aan die dag gelê en was hulle gewillig om ter wille van hul vaderland hul lewens af te lê..$^{62}$

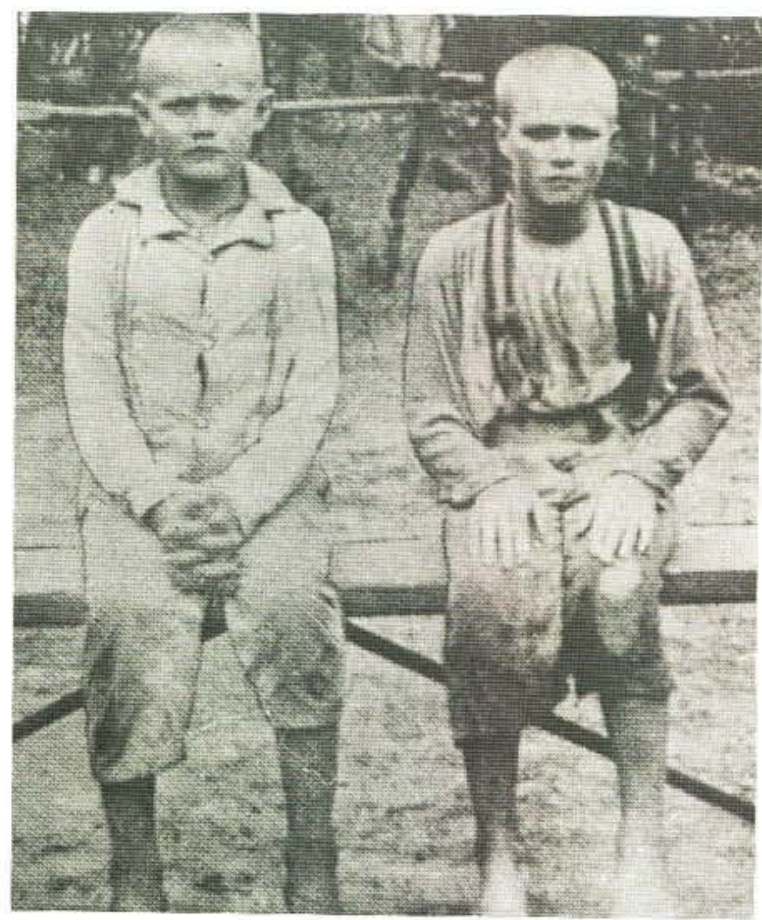

Pieter Cronje (9 jaar) en Tjaart van der Walt (11 jaar) as krygsgevangenes op die Bermuda-eilande 


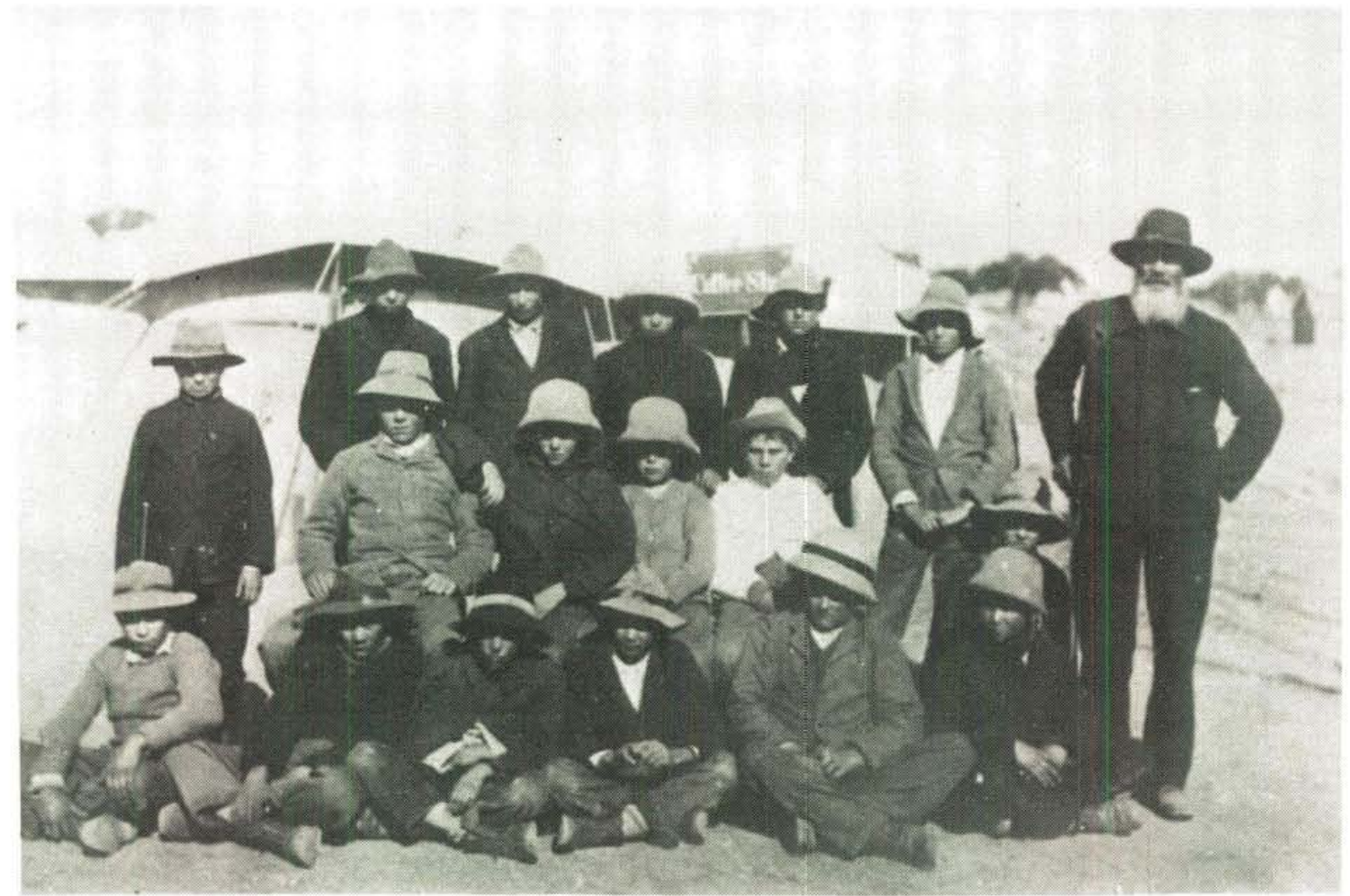

'n Groepfoto van 'n aantal Penkoppe wat gedurende dle Tweede Vryheidsoorlog gevange geneem en na 'n Krygsgevangekamp in Indië gestuur is. Hulle ouderdomme wissel tussen 8 en 14 jaar

Baie seuns van 12 en 14 jaar oud is as krygsgevangenes oorsee gestuur. Hulle is hoofsaaklik gestuur na St Helena, Bermuda, Ceylon en Indië. Daar was van die Penkoppe wat selfs nog jonger as 12 jaar was soos Pieter Cronje en Tjaart van der Walt wat onderskeidelik nege en elf jaar oud was. Die krygsgevangene Penkoppe op die Bermuda-eilande is op een eiland saamgetrek om daar skool te gaan waarin daar gepoog is om hulle te verengels. Baie penkoppe het geweier om deur ander mense as hul eie volks- en geesgenote onderrig te word en het die straf wat hulle vir hul weiering opgelê is, met gelatenheid aanvaar en verduur. ${ }^{63}$

Op 31 Mei 1902 is die Vrede van Vereniging gesluit en die twee Boererepublieke het hulle onafhanklikheid verloor. Sommige Penkoppe het onder groot protes hul wapens neergelê. Kort na die vrede is die Penkoppe wat in ballingskap verkeer het na Suid-Afrika teruggestuur. Met groot blydskap het hulle uitgesien om weer by hulle families aan te sluit maar groot en bitter was die teleurstelling vir sommige waar daar net ' $n$ vader of ' $n$ moeder of ' $n$ suster of ' $n$ broer oorgebly het; vir ander niemand meer nie en is hul as weeskinders agtergelaat. Al wat oorgebly het van hul ouerhuis was meestal 'n murasie, 'n ver- late plaas sonder enige vee. Saam met die ouer garde het hierdie Penkoppe van vooraf begin om die land weer op te bou. Uit die puin het die Afrikanervolk weer herrys sodat dit vandag moeilik is om te bemerk dat Transvaal en die Vrystaat vir byna dertig maande lank in ' $n$ slagveld omskep was. ${ }^{64}$

Die lewe in die kampe, die boerelaer en op die slagveld, waar die Penkoppe so lank vir volk en vaderland moes opoffer, word pragtig uitgebeeld in die gedig 'Die Jongste Burger', deur die digter A.G. Visser, wat as volg lui:

\section{Die Jongste Burger \\ I. Die Kamp}

In die kamp van die vroue heers stilte en donker Die ellende genadig bedek deur die nag.

Hier en daar in 'n tent nog ' $n$ flou liggeflonker, Waar die Engel van Meely - die

Doodsengel - wag

In die plaas van verdriet en van loodsware harte Lê 'n knapie te snik in 'n troost'loos' geween. $\mathrm{O}$ wie tel al die trane, wie meet al die smarte Van 'n weeskind verlate, op die wêreld alleen! 
Want sy vader was vroeg in die stryd al gesneuwel,

$\mathrm{Na}$ die kamp toe moes moeder toe die huis was verbrand

Sy en Sussie lê daar aan die voet van die heuwel;

"Wees getrou" het sy sterwend gesê "aan jou land!"

Maar meteens word hy stil, hou sy asem en luister:

Uit die verte verneem hy ' $n$ dowwe gedruis.

"Dit is waens en perde wat trek in die duister, "Soos die Boerekommando die aand by die huis."

En 'n vurig verlange laat ril al sy lede

By die denkbeeld: daar trek van ons mense verby,

En hy kruip by die skildwag verby, - net ' $n$ skrede -

Deur die doringdraad-heining. Goddank hy is vry.

Nie die grynsende nag, nog die skoot van die skildwag,

Nie die snerpende kou laat hom huiwer ... hy's weg ...

Half verkluim, by De Wet bring hom een van die brandwag:

"Generaal hier's 'n Burger wat ook kom help veg!"

\section{Die Laer}

Bleek word die held van 'n honderd gevegte;

Duister die anders so heldere oog.

"Moet ook ons kinders nog sterf vir ons regte?

"Vaderlandsliefde, $\mathrm{U}$ eise is hoog!

"Vryheid verg hier vanuit onse geleed're,

"Manne van moed wat gevare uittart.

"Maar in die kamp ook die moeder, die teed're,

"En die onskuldige kind aan haar hart.

"Wie by ons aansluit het net een verwagting:

"Daagliks die dood in die oë te kyk.

"Honger en dors te verduur met veragting;

"Nimmer die eindpaal of doel te bereik.

"Berg-oor waar nooit nog 'n hoefslag-gedonder, "Stroom-deur waar woes rol die bruisende vliet. "Krans-af waar swart gaap die afgrond daaronder;

"Blokhuis en haak-draad ' $n$ pad deur te skiet.
"Vlug as die springbok die vyand ontwykend, "Blitsnel hom later te spring in die sy;

"Nou soos die arend sy planne afkykend,

"Dan soos die leeu van hom buit weer te kry.

"En die beloning? ... Miskien op die velde "Eensaam 'n rusplaas, benat deur geen traan. "Eenmaal, wie weet? eer die nakroos ons helde.

"Seun, sien jy kans?" "Generaal, ek sluit aan!"

$$
\text { III Die Slag }
$$

Soos sprinkaneswerms kom van uit alle oorde Die vyand, toe die oggend die laer bestraal Van Môre en Awend, van Suide en Noorde! By De Wet net ' $n$ handvol, maar manne van staal.

Verniet al hul voetvolk en ruiters en bomme! Niks baat ook die driemaal verdubbeld' kordon; Hy breek soos ' $n$ warrelwind deur die kolomme Met agthonderd burgers en Danie Theron.

Die stofdamp verdwyn en die krygsrumoer swyg weer,

En sag daal die nag oor die bloedige veld, Waar buld'rende moordtuig en mouser nie dreig meer -

Sieltogend lê menige strydros en held.

Tesaam vriend en vyand. Die Rooikruis kry later 'n Arme klein seun met 'n koeël deur die bors: "Ag, Omie, bring gou tog vir my bietjie water; Die pyn kan ek uithou, maar $\mathrm{O}$, nie die dors!"

Gelaaf word sy lippe, verbind al sy wonde, Maar ru was die storm en die stingel gekraak, Diensvaardige Meelyde daar aan sy sponde Kon sien elke uur, hoe die Skadu genaak.

In brandende koors yl hy: "Daar kom van verre "'n Grote kommando ... hul roep my op my naam.

"Kyk, al die wit perde ... daar naby die sterre "O daar is my vader ... 'k gaan saam, ek gaan saam!"

Die oë word flouer en slapper die hande; 'n Glimlag verstyf op die koue gesig So sag as die aandson daar ver op die rande Nog rus, met 'n soengroet van liefde en lig!

${ }^{*}$ Mnr J.A. Visser, MA, TOD, is verbonde aan die Militêre Informasieburo van die SAW. 


\section{Verwysings}

1. Otto, J.C., Die Konsentrasiekampe, Nasionale Boekhandel, Kaapstad,

1954, pp 1-3.

2. Ibid., pp 6-7.

3. Ibid., p 36

4. Ibid. pp $37-40$

5. Symington, F.C., "Die Konsentrasiekampskole in die Transvaal en Oranje-Vrystaat." (Opgeneem in Historiese Studies, Jaargang 5, Nol), Universiteit van Pretoria, Maart 1944, p 5.

6. Otto, J.C., Die Konsentrasiekampe, p 41

7. Ibid.

8. Ibid., pp 43-48.

9. Ibid., pp 48-51.

10. Ibid., pp 51-52.

11. Symington, F.C., "Die Konsentrasiekampskole in die Transvaal en Oranje-Vrystaat", p 6.

12. Otto, J.C., Die Konsentrasiekampe, pp 57-61.

13. Ibid., pp $66-67$.

14. Symington, F.C., "Die Konsentrasiekampskole in die Transvaal en Oranje-Vrystaat", p 32.

15. Otto, J.C. Die Konsentrasiekampe, pp 69-77.

16. Ibid., pp 77-82.

17. Ibid., pp $83-84$.

18. Hobhouse, Emily, Die Smarte van Oorlog en wie dit gely het. (Uit Engels vertaal deur dr N.J. van der Merwe), Bloemfontein, 1942, p 297; Otto, J.C., Die Konsentrasiekampe, $p 83$.

19. Hobhouse, Emily, Die Smarte van Oorlog en wie dit gely het, p 295 Otto, J.C., Die Konsentrasiekampe, p 83.

20. Otto, J.C., Die Konsentrasiekampe, pp 84-85.

21. Ibid., p 88.

22. Stead, W.T. Methods of Barbarism. The Case for Intervention, Mowbray House, London, 1901, pp 9-10.

23. Otto, J.C., Die Konsentrasiekampe, p 91

24. Ibid., pp 91-98.

25. Ibid., pp $98-100$.

26. Ibid., p 100.

27. Ibid., pp 100-101.

28. Hobhouse, Emily, Die Smarte van Oorlog en wie dit gely het, p 102.

29. Otto, J.C., Die Konsentrasiekampe, p 103.

30. Ibid. pp 104-107.

31. Ibid., pp 104-118.
32. Ibid., pp 119-122.

33. Ibid., p 125.

34. Ibid., p 128.

35. Mac-Donald, Ramsay, What I saw in South Africa, September and October 1902, London, 1902, p 24.

36. Otto, J.C. Die Konsentrasiekampe, p 129.

37. Ibid., pp 130-132.

38. Ibid., p 138.

39. Hobhouse, Emily, The Brunt of the War and where it Fell, London, 1902, pp 138-139.

40. Otto, J.C., Die Konsentrasiekampe, p 140.

41. Ibid., pp 140-141.

42. Ibid., pp $145-146$.

43. Symington, F.C., "Die Konsentrasiekampskole in die Transvaal en Oranje-Vrystaat", pp 6-7.

44. Hobhouse, Emily, Die Smarte van Oorlog en wie dit gely het, Aanhangsel A, pp 294-295.

45. Otto, J.C. Die Konsentrasiekampe, pp 146-148.

46. Ibid., pp 149-150.

47. Symington, F.C., "Die Konsentrasiekampskole in die Transvaal en Oranie Vrystaat", pp 65-67.

48. Kotzé, D.J., Dapper Kinders van Suid-Afrika, Die Sondagskool-Boekhandel, Bloemfontein, s.j., p 130-131.

49. Ibid., p 130

50. Ibid., pp 130-131.

51. Ibid., $p 133$

52. Ibid.

53. Ibid., pp 133-135.

54. Ibid., $p 135$

55. Ibid., p $135-136$

56. Ibid., pp 139-140.

57. Ibid., $p 141$

58. Ibid., pp $143-148$.

59. Röhm, E.F., "Kinders op Kommando", Die Huisgenoot, 22 Januarie 1943, p 8.

60. Ibid.

61. Ibid

62. Nöthling, C.J., "Kardinale Aspekte van Nasionale Diensplig met Spesifieke Verwysing na Suid-Afrika", Militaria 12/3, 1982, p 37.

63. Kotzé, D.J. Dapper Kinders van Suid-Afrika, p 149

64. Ibid., p 150. 